Canadian Journal of Fisheries and Aquatic Sciences

Canadian Science Publishing

Journal canadien des sciences halieutiques et aquatiques

\title{
Modeling and mapping fish abundance across wadeable streams of Illinois, USA based on landscape-level environmental variables
}

\begin{tabular}{|r|l|}
\hline Journal: & Canadian Journal of Fisheries and Aquatic Sciences \\
\hline Manuscript ID & cjfas-2015-0343.R2 \\
\hline Manuscript Type: & Article \\
\hline Complete List of Authors: & $\begin{array}{l}\text { Cao, Yong; Illinois Natural History Survey } \\
\text { Hinz, Leon; University of Illinois, Illinois Natural History Survey } \\
\text { Metzke, Brian; University of Illinois, Illinois Natural History Survey } \\
\text { Stein, Jeffrey; University of Illinois, Illinois Natural History Survey } \\
\text { Holtrop, Ann; IL Department of Natural Resources, }\end{array}$ \\
\hline Keyword: & $\begin{array}{l}\text { MODELS < General, STREAMS < Environment/Habitat, ABUNDANCE < } \\
\text { General, FRESHWATER FISHES < General, HABITAT < General }\end{array}$ \\
\hline \multicolumn{2}{|c}{} \\
\hline
\end{tabular}

SCHOLARONE ${ }^{1 m}$

Manuscripts 
Modeling and mapping fish abundance across wadeable streams of Illinois, USA based on landscape-level environmental variables

$$
\text { Yong } \mathrm{Cao}^{1 *} \text {, Leon Hinz }{ }^{1} \text {, Brian Metzke }{ }^{1} \text {, Jeffrey Stein }{ }^{1} \text {, Ann Holtrop }{ }^{2}
$$

${ }^{1}$ Illinois Natural History Survey, Prairie Research Institute, University of Illinois

${ }^{2}$ Illinois Department of Natural resources

* correspondence author, email: yongcao@illinois.edu; phone: 2172446847. 
1 Abstract: To effectively conserve and restore stream ecosystems, we need to better understand the

2 distribution and abundance of individual fish species in relation to natural environments and

3 anthropological stressors. In this study, we modeled the abundance of 97 fish species in small wadeable

4 streams of Illinois, USA, based on random-forests regression and landscape-level environmental

5 variables. Model $R^{2}$-values for intermediately-common species were higher than for common species,

6 but highly variable among rare ones. Models for 50 species reached $R^{2}$ of $0.2-0.70$ and were tested

7 with a separate set of samples and applied to unsampled wadeable reaches to show the population

8 hotspots of each species across the state. Furthermore, we evaluated the importance of individual

9 environmental variables to a given fish species as well as the directional responses of each species to top

1010 key predictors. Climate and land-use were the best predictors for most species, followed by

11 topography, geology, and soil permeability. Spatial connection of a stream also was associated with a

12 large number of species. These findings improved our understanding of the relationships between fish

13 species and landscape environments. The distribution maps could guide resource management,

14 restoration, and monitoring of stream fish assemblages.

15

16 Key words: species abundance model, freshwater biodiversity, random forests, fish-environment 17 relationship, prairie streams. 


\section{Introduction}

20 How individual species and species diversity are distributed across space in relation to both natural

21 and anthropological factors has been a central question in ecology for a long time (Forbes 1908;

22 Andrewartha and Birch 1954; Royle et al. 2007). This knowledge is of great importance for addressing a

23 wide range of basic and applied issues, particularly for effective biodiversity conservation and

24 environmental management (Oberdorff et al. 2001; Royle et al. 2007). Species modeling is the main

25 avenue to quantify the relationships between species and their environments based on limited sampling

26 data, and to predict the presence or abundance of species at unsampled locations, or to predict

27 potential changes in the future (Peterson et al. 2011). In the past decade, a great deal of research effort

28 has been directed toward species modeling (Elith and Leatherwick 2009; Peterson et al. 2011), but

29 mainly in terrestrial ecosystems (Soininen and Luoto 2014).

30 In freshwater ecosystems, fish species modeling (Oberdorff et al. 2001; Oakes et al. 2005; Steen et al.

31 2008; Lyons et al. 2010) has led to better understanding of fish-environment relationships and provided

32 valuable information for effective resource management (Wenger et al. 2008; Esselman and Allan 2010).

33 Based on our review of 70 peer-reviewed publications on stream/lake fish species modeling found for

34 2000-15 via Web of Science and Google Scholar (Appendix 1), we identified a number of trends and

35 knowledge gaps. First, most studies (81\%) modeled the presence-absence of species. The occurrence

36 probability of a species at a location provides a basic description of the potential species range and

37 potential shifts under changing climate and landuse (Wenger and Freeman 2008; Lyons et al. 2010).

38 However, this information may not be adequate for many other purposes, such as the management of

39 sportfish or common fish species, identification of most viable populations, or the estimation of

40 ecosystem functions. Information on species abundance is required for these needs, yet species

41 abundance was modeled in only approximately $20 \%$ of the studies, and was often restricted to one or a

42 few species, such as salmon and trout (Wenger and Freeman 2008; McKenna and Johnson 2011).

43 Modeling of common and non-sport species has been rare, in spite of their critical roles in ecosystem

44 processes (e.g., productivity and nutrient cycles), and sometime high sensitivity to landuse changes (Utz

45 2014). A second trend is that about half of fish species models examined were at least partly based on

46 local habitat variables, such as substrate type and water depth. Those models can offer insights into how

47 local habitats affect fish species, but such models are difficult to apply to the great number of

48 unsampled locations (i.e., no habitat data available), an issue that constrains the utilities of the models.

49 For example, we would need species distributions across the whole study region to prioritize streams for

50 conservation and restoration (Merovich et al. 2013; Stoll et al. 2013, 2014). A last trend is that most 
51 studies were restricted to a single river basin or a region defined for the specific purpose of a project.

52 However, many conservation, restoration, and environmental programs are established and managed

53 by a jurisdictional entity, such as a state in the US. For many of these programs there is a clear benefit to

54 use the boundaries of a state or province as the spatial extent in modeling.

55 In the present study, we attempted to fill some of the knowledge gaps by developing and applying

56 abundance models for a large number of fish species, including most common ones in wadeable streams

57 in Illinois, USA. Based on a wide range of landscape-level variables summarized at stream reach level and

58 a robust machine learning approach, the models provide valuable information on species distribution at

59 a relevant spatial scale in resource management. We further asked three specific questions: 1) how

60 stream fish species are generally associated with natural environmental environments (climate, geology,

61 watershed topography, etc.) versus human alternations in land use and spatial connections in a

62 agriculturally-dominated region, 2) what environmental variables were most strongly associated with

63 each individual fish species modeled, and how, and 3) how the strength of fish-environment

64 associations, as measured with model $R^{2}$-value, varied with species rarity, and why. The answers to

65 these questions will improve our understanding of fish -environment relationships and help us to assess

66 the future impacts of broad-scale human disturbances (e.g., urbanization and climate changes) on

67 stream ecosystems.

\section{Data and Methods}

\section{Fish Sampling Data}

Illinois Department of Natural Resources (IL-DNR) and Environmental Protection Agency (IL-EPA)

72 jointly initialed a statewide stream monitoring program (the Intensive Basin Survey) for the state

$73\left(149,998 \mathrm{~km}^{2}\right)$ in 1981. Thirty-six major river basins were established as a framework of survey design for

74 the state monitoring programs of fish, aquatic macroinvertebrates, stream habitat, and basic water

75 quality. State and local fisheries biologists selected sampling sites to be representative of each basin in

76 terms of stream size, type, known diversity hotspots, point sources of pollution, and to include sites that

77 were sampled in the past (IL-EPA 1996).

78 At each sampling site in a wadeable stream, a stream segment of 20 channel-widths (no less than

$79100 \mathrm{~m}$ and no more than $300 \mathrm{~m}$ ) was selected for sampling with one-pass electro-seining $(9.14 \mathrm{~m})$, a

80 highly effective method developed and used in Illinois since the 1960s (Bayley et al. 1989), or backpack

81 electrofisher in small streams (IL-DNR 2010). For streams wider than approximately 9m, one pass for

82 each half was carried out. On average, this sampling effort captures $>70 \%$ of all species in a sampled 
83 reach (Holtrop et al. 2010). To better characterize the current state of fish populations and diversity, we 84 only included those samples collected between 1995 and 2010. Streams of Midwest US, including Illinois, 85 are generally productive and specious (Smith et al. 2010), 10-30 fish species per site (Moyle and Herbold 86 1987). All samples containing fewer than 20 fish individuals and fewer than five species were thus likely 87 resulted from unsuccessful field operation and removed. Because electric seine could not cover the 88 whole channel in a wide stream, we further excluded those sites where wet-channel width greater was 89 than $18 \mathrm{~m}$. As a result samples of 701 wadeable small stream sites were retained (Fig. 1). The width of 90 wet channel at the sites ranged from 0.76 to $18 \mathrm{~m}$ (average $8 \mathrm{~m}$, standard deviation or SD $=3.1 \mathrm{~m}$ ), and 91 the sampling areas from 64 to $5523 \mathrm{~m}^{2}$ (average $1112 \mathrm{~m}^{2}, \mathrm{SD}=1450 \mathrm{~m}^{2}$ ) These sites were not randomly 92 selected, however they are well spread across the state, presumably represent all major basins and 93 capture key environmental gradients in the study region. When multiple yearly samples were collected 94 from a site, we averaged the abundance of each species and standardized it as the number of individual 95 per $1000 \mathrm{~m}^{2}$. Understanding that catchability of individuals in any species is rarely, if ever, perfect in field 96 sampling, we took the standardized abundance as an index of the true abundance.

97 A second dataset was derived from a separate project in Kaskaskia River Basin, IL, a major tributary 98 of Mississippi River (Fig. 1). Samples were collected from 109 reaches $(0.75-10 \mathrm{~m}$ wide) using the same 99 field protocol during the summers of 2013-15. Based on the same sample selection criteria described 100 above, samples from 104 reaches were retained for model validation.

101

\section{Spatial Framework and GIS-based environmental data}

Our species modeling was based on a spatial framework and the associated environmental database

104 developed by the Great Lakes Regional Aquatic Gap Analysis Project (Brenden et al. 2006; Steen et al.

105 2008; McKenna et al. 2013; Cao et al. 2015). The basic spatial unit of a stream network is a reach, 106 defined as a stream section from the confluence of an upper-stream tributary to the confluence of a 107 down-stream tributary (based on a 1:100,000 map of US National Hydrology Dataset). Environmental 108 variables on climate, geology, and others were summarized at four spatial levels: 1) the total watershed 109 (WT), the drainage above the downstream confluence of the reach; 2 ) the local watershed (W), the area 110 that directly drains into a reach; 3) the 30-m riparian zone in the total watershed (RT); and 4) the 30-m 111 riparian zone in the local watershed $(R)$.

112 More than 300 environmental variables originally compiled the four spatial scales include detailed 113 geological and land-use categories (e.g., different types of urban lands and moraines) for multiple states 114 in the Great Lakes region of the US. The data sources, spatial resolutions and time periods used varied 
115 with types of variables and were detailed in Brenden et al. (2006). Steen et al. (2008) and Seelbach et al.

116 (2010) combined similar categories (e.g., different types of urban lands) into a major group (e.g., urban

117 land). We adopted their grouping in this study to reduce the number of predictor variables, assuming

118 that the majority of information was retained by the major groups. We further removed those variables

119 that have few non-zero values in Illinois (e.g., certain types of geology), and ended with 110 variables.

120 Strong correlations, negative or positive, mean data redundancy for modeling. The absolute value of

121 Pearson $r(|r|)$ was greater than 0.8 for 90 pairs of variables. To reduce variable co-linearity, we

122 conducted cluster analysis based on $|r|$ and unweighted-group-mean algorithm. Twenty-one highly-

123 compacted groups were identified (2-9 per group, within-group $|r| \geq 0.9$ ) (Supplementary 1). While

124 keeping all other variables, we chose the variable that seemed most biologically meaningful from each

125 group (e.g., growing-degree-days in a temperature-related group), or selected one at random if no such

126 a judgment could be made. As a result, 65 variables were retained with average $|r|$ of 0.13 and $|r|$ slightly

127 great than 0.8 only in 7 pairs (2145 pairs in total). We kept the 7 pairs because they did not appear

128 environmentally redundant (e.g., slope and forest land) and the modeling method we used for this study

129 is much more resistant to co-linearity than parametric regression methods. These variables were

130 classified into seven categories: stream size, climate, connection, geology, landuse, soil, and topography

131 (Appendix 2). All these types of environmental variables were shown to be important at least for some

132 species (e.g., Wang et al. 2000; Alan 2004; Smith et al. 2010; Stoll et al. 2014).

\section{Model calibrations}

135 Abundance of a species is often associated with high sampling variability and this variability

136 increases with the mean (Gaston and McArdle 1994). To reduce the effects of sampling variability, we

137 transformed the raw data with $\log (x+1)$ for all species. We examined the number of sites where a

138 species was recorded, and excluded species occurring at $\leq 10$ sites for modeling.

139 Random forest regression (RF) (Breiman 2001) is advantageous over many conventional regression

140 methods when used to model the complex responses (linear, non-linear, or threshold) of species to a

141 large number of inter-correlated and potentially interacting environmental variables (Cutler et al. 2007).

142 This method also appears robust to overfitting (Breiman 2001) and the effects of autocorrelation

143 (Karpievitch et al. 2009; Stuart-Smith et al. 2013), a major concern in modeling (Dormann et al. 2007). A

144 test on one basin (Upper Illinois River) showed the waterway distance for $99.3 \%$ of site pairs $\geq 10 \mathrm{~km}$, a

145 likely upper limit of dispersals by most stream fish species (Stoll et al. 2013; Radinger and Wolter 2014).

146 Therefore, spatial autocorrelation in our dataset should be weak if present. 
$\mathrm{RF}$ is a bootstrapping version of classification tree. A tree model recursively splits a group of samples based on a selected predictor to minimize the variance (Breiman 1984). In RF modeling, one randomly draws a small number (i.e., mtry in R-package randomForest) of predictors to build a tree using $2 / 3$ of the sample and then applies the tree to predict the other $1 / 3$ (out-of-bag sample). One can repeat this process many times (5000 in our case) and average the predictions from each tree model. We built a series of RF models by progressively increasing the number of predictors used for splitting a sample

153 group until the pseudo- $R^{2}$ stabilized. The number of variables needed for a stable $R^{2}$ is often far smaller 154 than $1 / 3$ of number of predictors, a factor that can further reduce potential overfitting.

155 RF uses a unique way to assess the importance of a given predictor. After the order of a predictor in 156 the out-of-bag samples is randomized, the original site-environment matches no longer exist. If the 157 predictor is important, mean standard error (MSE) of the predictions will then increase substantially, 158 and vice versa. Many predictor variables may be important in a model, but the top 10 predictors are 159 typically presented and analyzed (Kuhn and Johnson 2013; Cao et al. 2015). The overall importance of a 160 given variable was measured as the number of models that ranked it within the top 10 predictors, and 161 the average and maximum \% increase of MSE across all models. To evaluate the relative importance of 162 different variables for a given species, we counted the number of variables in a category (e.g., climate) 163 that were ranked in the top 10 predictors and identified the highest rank. The response of species 164 abundance to a given predictor was examined with a partial-dependence plot, which averages out the 165 effects of other predictors. The directions of responses were classified into three types, positive, 166 negative, and multimodal. For the top 10 predictors we counted the number of species whose responses 167 to a given variable fell into each of these three categories. We measured how well a model performed 168 with $R^{2}$-value and related the performance to the number of sites where a species was recorded 169 (prevalence).

170 It is important to assess the uncertainty of predictions by a model (Beale and Lennon 2012). A 171 number of factors may contribute to the uncertainty, including replicate variability, seasonal/inter172 annual variation, estimation errors in environmental variables, and modeling errors. In this study, we 173 were only able to evaluate the last one, i.e., modeling error. For conventional methods, one can 174 estimate the confidence limits of each model parameter and the $95 \%$ confidence limits of predictions. 175 However, RF regression is non-parametric and the uncertainty cannot be assessed in the same way. We 176 created 10 replicate models for six selected species that differed in model performance (Table 1), by 177 using different random seeds (i.e., different sets of random tree models). We then calculated the 
178 coefficient of variation (CV) for the 10 predictions of each species in each reach and correlated it with

179 latitude and longitude of a reach, with which climate and many other variables co-vary.

\section{Model validation and application}

182 Although RF modeling always uses out-of-bag samples to calculate $R^{2}$ (internal validation), an 183 external validation was also conducted. We calculated the Pearson correlations between the observed 184 values at 108 validation reaches and their predictions by individual species models. These comparisons 185 included only those species that were modeled with $R^{2} \geq 0.20$, and recorded at $\geq 5$ validation reaches.

186 We assessed model performance using Spearman rank correlations between the predictions and 187 observations (Pineda and Lobo 2009). A strong correlation would be sufficient to identify similar sets of

188 reaches as population hotspots of a given species in a region and put a given stream in a similar rank for conservation.

190 We took two step to identify small wadeable streams to which our models can be applied. First, we

191 used the maximum watershed size and the highest number of the $1^{\text {st }}$-order stream reaches (links) in

192 the total watershed among 701 sampling sites to identify stream reaches across the state as high-likely

193 wadeable. Second, we built a random-forests classification model based on the same set of

194 environmental variables used for species modeling to predict whether a stream was $\leq 18 \mathrm{~m}$ wide. The 195 model reached an error rate of $5 \%$ and identified 46443 wadeable reaches that were likely $\leq 18 \mathrm{~m}$ wide.

196 The models that explain meaningful amounts of variance $\left(R^{2}>0.2\right.$ in our case) were applied to all 197 unsampled small wadeable stream reaches. The predictions were then transformed back to abundance per $1000 \mathrm{~m}^{2}$ stream wet channel.

199 Species-specific abundance classes, four for abundant species and three for less abundant ones,

200 were established for mapping to best show the spatial variation of abundance, which are associated 201 with potentially high prediction errors. To illustrate the detailed spatial patterns of species abundance 202 predicted, we also mapped the local watershed of a reach (as defined earlier), rather than the reach per 203 se (also see Cao et al. 2015), recognizing the local watershed size is not always proportional to the 204 length of a reach.

\section{Results}

207 We recorded 130 species at the 701 small wadeable sites with 97 recorded at $>10$ sites (Table 1). 208 Across the state, bluntnose minnow and green sunfish (see Table 1 for species scientific names) are 209 most common, occurring at $\geq 89 \%$ of sites, followed by bluegill and white sucker, at $>77 \%$ sites. Central 
210 stoneroller, bluntnose minnow, and sand shiner are most abundant (on average 50-87 individuals per

$\left.2111000 \mathrm{~m}^{2}\right)$. More widely distributed species tended to be more locally abundant $(r=0.68, p<0.01)$,

212 however, some species occur widely in relatively low numbers, such as yellow bullhead, largemouth

213 bass, and blackside darter. The number of species captured in a reach varied greatly (5-40), 18.7 on

214 average $(S D=5.6)$, indicating substantial variation in across streams.

215 We built RF abundance models for 97 species recorded at $\geq 10$ sites based on 2-8 environmental

216 variables (median $=4)$ for a split. $R^{2}$-value for the model varied substantially among species $\left(0.0 \leq R^{2} \leq\right.$

217 0.70), and was strongly and nonlinearly related to species prevalence (Fig. 2). $R^{2}$ for species of

218 intermediate prevalence were generally high, but low for common species. The performance of models

219 for rare species was highly variable. Fifty species models achieved $R^{2}$-values $\geq 0.20$, a minimum

220 performance with which we considered a model to be useful in this study.

221 We applied the RF models of the 50 species to all wadeable stream reaches across the state. After

222 the predicted abundance was transformed back to the number of individuals in a standard sample, we

223 then mapped estimates of abundance of each species in the state (see Figs. 3 and Supplementary Data 2

224 for 10 more examples). The population hotspots of most species were evident, such as the Kankakee

225 River in the northeastern of the state for smallmouth bass (dark green areas in Fig. 3b), and Central-

226 eastern Illinois for greenside darter (Supplementary Data 2).

227 The CV of abundance predictions across 10 replicate models for the six example species were all low,

$228 \quad 0.04-0.05$ on average with $\mathrm{CV}<0.1$ at $\geq 99 \%$ of the reaches, indicating low modeling uncertainty in

229 general. The correlations between CV and latitude or longitude were all weak in the six species $(-0.22 \leq r$

$230 \leq 0.33,-0.11 \leq r \leq 0.11$, respectively), indicating no clear spatial trends in modeling uncertainty. In model

231 validation, out of 50 species recorded from the 103 validation reaches in Kaskaskia River Basin, 27

232 recorded at $\geq 2$ reaches were tested. The Spearman rank correlation between the predicted and

233 observed abundance varied substantially among the species $(0.0 \leq r \leq 0.57$, on average 0.37$)$ (Table 2$)$,

234 indicating somewhat high prediction errors.

235 The overall importance of individual environmental variables for fish species abundance were first

236 assessed based on variable ranks for \% MSE Increase and the average (Supplementary data 3). Three

237 climate variables at the total-watershed level, growing-degree-days (WT_GDD), July-minimum

238 temperature (WT_JMin), and annual precipitation (WT_Precip) were the most important predictors,

239 being ranked in the top 10 predictors by 46-49 species, and yielded high average \% MSE Increase (23.4 -

240 23.8). They were followed by three of the other total-watershed variables, soil permeability (WT_Perm)

241 and \% of forest lands (WT_Perm), and \% of agricultural land (WT_Agri) ranked as the top 10 predictors 
242 by 33 and 36 species, respectively (17-18.4\% MSE increase on average). Other key predictors included

243 the total-watershed slope (WT_Slope), \% of WT with bedrock depth <15m (50 feet) (WT_BR50).

244 Noticeably, some other variables were greatly important for one or a few species in spite of their low

245 average importance, such as channel gradient ( $\left.\mathrm{CH}_{-} \mathrm{Grad}\right)$, and \% of bedrock of Shale at the total-

246 watershed level (WT_Shale), for instance, six species were closely associated with high channel gradient,

247 including central stoneroller, orangethroat darter, and fantail darter.

248 We then grouped the top 10 environmental predictors into 7 major categories and assessed the

249 overall effects of each category on specific species (Table 1) based on the number of species that ranked

250 any variables in a given category in the top 3 predictors. Multimodal species responses to an

251 environmental variable likely resulted from its interactions with other variables, and such responses are

252 difficult to interpret. We thus focused on clearly defined responses, i.e., positive or negative below,

253 starting with the most important category.

254 1) Climate. RF models ranked climate in the top three predictors for 43 of 50 species and in the top

25510 for 49 species (Table 1). We observed more negative responses than positive ones to temperature

256 and precipitation (Appendix 3). For example, 26 species decreased with increasing growing-degree-days

257 (WT_GDD) (e.g., smallmouth bass, horneyhead chub, and common shiner), but 12 increased (e.g.,

258 longear sunfish) (Fig. 4a). Similarly, 23 species negatively responded to annual precipitation in the total

259 watershed (WT_Precip) while 19 responded positively.

260 2) Land use. Ten species ranked land use in the top three predictors, and all 50 species in the top 10,

261 showing its broad significance (Table 1). Among 10 land-use variables, \% of forest lands (WT_Forest)

262 and \% of agricultural land (WT_Agri) in the total watershed were most important. Fifteen species

263 decreased with WT_Forest, and 11 species increased. In comparison, 25 species increased with WT_Agri,

264 but only 5 species decreased (Fig. 4b, Appendix 3). Only five species ranked \% of urban land in the total

265 watershed (WT_Urban) in the top 10 predictors, and none in the top three. The other land uses (e.g.,

266 grassland and water) were related to fewer species negatively or positively.

267 3) Stream and watershed topography. Chanel gradient ( $\mathrm{CH}_{-}$Grad) and watershed slope (WT_Slope)

268 were ranked in the top 3 predictors by 10 species, and in the top 10 by 35 species (Table 1). Slightly

269 more species preferred high-slope than low-slope streams. For example, 13 species were positively

270 related to WT_Slope (e.g., shorthead redhorse), but 12 negatively (e.g., striped shiner, golden shiner,

271 and longear sunfish, see Fig. 4c, Appendix 3).

272 4) Geology. Seven and 42 species ranked geology in the top 3 and 10 predictors, respectively (Table

273 1). The most commonly ranked variable was $\%$ of the total watershed with bedrock depth $<15 \mathrm{~m}$ 
274 (WT_BR50). Eight species (e.g., pirate perch) increased with WT_BR50, but 16 species decreased (e.g., 275 northern hogsucker, redfine shiner, and striped shiner) (Fig. 4d, Appendix 3). Percent watershed with 276 bedrock deeper than approximately 50m (100 Feet) (WT_BRG100) was also important, being positively or negatively associated with 11 and 4 species, respectively. Smaller numbers of species were associated with other types of geology.

5) Soil permeability. Seven species ranked this category of variables in the top 3 predictors, and 39 in

280 the top 10 (Table 1), including 20 species positively associated and 8 species negatively with soil 281 permeability in the total watershed (WT_Perm) (Appendix 3). As expected, those species that prefer

282 lentic habitats, such as green sunfish and pirate perch tended to decrease with increasing soil 283 permeability while typical lotic species, such as smallmouth bass and fantail darter tended to increase 284 (Fig. 4e).

6). Stream size. Seven species ranked one or more variables of this category as a top 3 predictor, and 17 species as a top 10 (Table 1). Eleven species increased with Link (e.g., shorhead redhorse, channel catfish), and 5 three decreased, including creek chub and white sucker, typical smaller stream species in Illinois. Fourteen species ranked the total-watershed size as the top 10 predictor, half positively associated and half negatively.

7) Spatial connection. This group of variables seems least important, yet were ranked in the top 3

291 predictors by six species, and in the top 10 by 25 species (Table 1). Distance to downstream dam

292 (Damdn_L) was most important, with which 13 species increased (e.g., northern hogsucker, shorthead

293 redhorse, smallmouth bass), and two species decreased (e.g., spotfin shiner and blackspotted

294 topminnow) (Fig. 4f, Appendix 3). Nine species increased with the distance to downstream

295 ponds/impoundments, but one decreased.

296 In summary, climate appeared to be the most important for stream fish species in the study area,

297 followed by land-use, stream topography, geology, and soil permeability. Spatial connection also was 298 associated with a considerable number of species.

\section{Discussion}

301 Freshwater ecosystems have been deteriorating across the world and contain the greatest 302 proportion of species classified as extinct, endangered and threatened of the major ecosystem types 303 (Dudgeon et al. 2006; Strayer and Dudgeon 2010; Burkhead 2012). Species distribution models (SDM) as 304 valuable tools to assist protection and restoration of fish biodiversity have attracted substantial research 305 efforts (Peterson et al. 2011). However, fish species modeling is typically restricted to presence-absence, 
306 small numbers of species or small spatial scales (Appendix 1), inadequate for general biodiversity 307 conservation and management at the broad spatial scale. In the present study, we developed SDMs for 308 the abundance of 97 species occurring in wadeable streams of Illinois, USA, probably representing one 309 of the largest modeling effort for freshwater fish to date. Because all predictors were derived at the 310 landscape level, the species models could be applied to all $>46000$ stream reaches in the study region 311 for 50 species, and provide a valuable tool for management and data for future research.

312 Our predictions and mapping of species abundance across all small wadeable streams in the study 313 region can help fish management and restoration in several ways. First, resource managers can readily 314 use the maps to identify the reaches that are likely to be highly populated by a given species. However, 315 the observation-prediction correlation was not strong in validation (Table 2), and therefore clustered 316 population hotspots would be more reliable than isolated ones. Among other potential applications of 317 the maps are 1) identifying what forms of protection these areas are under (e.g., state parks, National 318 Forests, conservation easements, and wildlife refuges) (see Lawrence et al. 2011), and 2) which species 319 are most vulnerable to planned land-use changes (i.e., urbanization) and overall human disturbances. 320 Based on the spatial patterns of species abundance, resource managers also may adjust their monitoring 321 and restoration programs accordingly (Merovich et al. 2013; Stoll et al. 2014). For example, they can 322 maximize the benefits of Conservation Reserve Program (Allen and Vandever 2012) by focusing on those 323 streams that are in poor condition, but with good accesses to populated streams.

324 How fish species are distributed in relation to their environment has been a central theme in aquatic 325 ecology for a long time, particularly in the State of Illinois (Forbes 1908; Larimore 1963; Smith 1979). Our 326 modeling provided rich information on species-environment relationships at the landscape scale (Table 327 1), which helps data synthesis of fish-environment relationship and may lead to development of new 328 hypotheses regarding the response of a species to a specific environmental variable. The associations of 329 individual fish species with most natural factors, climate, channel/watershed slopes, and geology were 330 highly variable (Table 1, Appendix 6), suggesting niche partitioning of species along these natural 331 environmental gradients. Fish-climate relationships are particularly important and complex. More 332 species were associated with low WT_GDD and WT_Precip than with the high, suggesting broad effects 333 of climate changes. Any specific association, however, may suggest the response of a species to climate, 334 or may simply be the result of co-variation (Olden et al. 2002). For example, Ozark minnow occurs in the 335 hilly northwestern corner of the state (Driftless Area), where substrates are largely pebble/gravels, and 336 water is relatively clear. It also widely occurs in similar habitats in the Ozark Plateau in the South and 337 Wisconsin and Minnesota in the North. Thus, climate is unlikely to be the limiting factor. However, the 
338 climate in the driftless area happens to be cold and dry, compared with the rest of the state. The co339 variation appears to lead the RF model to ranking WT_GDD, WT_Precip, and WT_JMin high. One may 340 avoid this type of compounding effect by developing a model for a species based on data from its whole 341 range (or most of it), something that is particularly important to predict the impact of climate change 342 (Barbert-Massin et al. 2010). If required data are unavailable, one at least should carefully review the 343 ecology of a species, particularly its known range before including climate variables into a regional 344 species model for predicting climate-change impacts. For cool-water species, such as smallmouth bass, 345 common shiner, mottled sculpin in IL (Hinz et al. 2011), our RF models should be useful to assess 346 potential future changes under changing climate.

347 Although natural environmental variables, particularly climate, remained to be best predictors of 348 abundances in most species (Table 1, Supplementary Data 3), land-use in the total watershed, and to a 349 lesser extent the dams/impoundments also were strongly associated with a large number of species.

350 This result is expectable as the landscapes of Illinois have been greatly altered over past 100 years with 351 once-dominated wet prairie and marshes replaced by farmlands and urban areas (Iverson 1988).

352 Interestingly, many fish species tended to increase with \% of agricultural land in the total watershed, but 353 decreased with \% of forest land, something that does not seem intuitive. However, in our study region, 354 most forests are located in the southern and western parts of the state near the Mississippi and Illinois 355 Rivers, where flows are unstable and habitats relatively poor. Furthermore, the third major land-use, 356 urban land, is highly detrimental to aquatic ecosystems (Paul and Meyer 2001; Allan 2004). As a result, it 357 is not surprising to see streams in agriculture-dominated landscapes supporting large fish populations in 358 the state. Similar findings were reported for Wisconsin fishes (Wang et al. 2000) and Illinois mussel 359 species (Cao et al. 2015). In comparison, the negative effects of impoundments and dams on abundance 360 of most species are consistent with many previous studies (Wang et al. 2011; Nislow et al. 2011).

361 For either resource management or inferences of fish-environment relationships, the utilities of 362 species models depend on model performance. $R^{2}$-values were low for many rare species (Fig. 2). Most 363 of those species typically occur in large rivers/streams, only sporadically in small wadeable streams (e.g., 364 river shiner, yellow bass, and black buffalo), and a weak association with stream environment variables 365 is thus expected. In comparison, those well-fitted rare species often occur in wadeable streams of 366 restricted areas (e.g., Ozark minnow, bigeye shiner, and common shiner). Therefore, rarity per se does 367 not appear necessarily related to model performance. Extremely common species also had poor fits in 368 this study (Fig 2), probably because some important local habitat variables or biological processes (e.g., 369 food supplies and predations) were missed from our modeling. This non-linear relationship between 
370 rarity and model performance contrasts with their positive and consistent relationships in previous 371 studies (McPherson and Jetz 2007; Newbold et al. 2009; Franklin et al. 2009).

372 Prediction uncertainty, an important issue in species modeling, can be affected by multiple sources

373 (Beale and Lennon 2012). The uncertainty associated with modeling per se in the present study

374 appeared to be minor $(\mathrm{CV}<0.1)$. However, the overall prediction accuracy was not high in the validation

375 (i.e., low correlation $r$, Table 2). One possible explanation is that all the validation sites used were in a

376 single river basin, but the models were built to achieve a state-wide statistical optimum. A more

377 probable explanation is that our modeling did not consider replicate variability and seasonal and inter-

378 annual variation, all of which can be substantial (Grossman et al. 1990; Peterson and Rabeni 1995).

379 Incorporating local habitat variables and weather conditions in the sampling year into modeling could

380 improve model accuracy, but constrain model applicability.

381 To ensure the applicability of models to unsampled streams reaches, we also had to exclude several

382 other environmental factors which are known to be important to fish abundance, a step that may

383 contributed to the low $R^{2}$ for many species models. Among these factors are water quality and flow

384 stability and discharge (Allen 2004; Blann et al. 2009). Although we included a range of landscape

385 variables that are normally used to predict these factors (Richards et al. 1996; Tong and Chen 2002;

386 Frederico et al. 2014), their direct modeling and prediction at the reach level could significantly improve

387 fish model performance. Biological processes, such as competition and predation can also play a

388 significant role in explaining species abundance and distribution (Godsoe and Harmon 2012; Trainor and

389 Schmitz 2014), but were not included in our models, either, because these types of data are rarely

390 available from field surveys and not available at unsampled sites. Imperfect and variable catchability of

391 fish individuals likely further affected the $R^{2}$ values. Fish catchability often varies with habitat

392 characteristics (Bayley and Austen 2002; Price and Peterson 2010). Individual catchability can be

393 incorporated into species-abundance modeling, but such studies are normally focused on a single

394 species (e.g., Wenger and Freeman 2008). It is a challenge to incorporate the catchability for a large

395 number of species in a region as this requires collecting multiple spatial or temporal replicates and

396 detailed habitat information at large numbers of sites (Johnson 2008; Bank-Leite et al. 2015). The

397 statistical adjustments for catchability, however, may be not always effective (Welsh et al. 2013, but see

398 Guillera-Arroita et al. 2014).

399 It is even more challenging to model rare species, like those recorded at $<10$ sites in the present

400 study while such models are most needed for conservation. Routine fish monitoring needs to be

401 supplemented by additional field sampling that target specific rare species and use the most effective 
402 collection methods for these species. Joint species distribution models that use information from co-

403 occurrence of rare species with common ones (Harris 2015; Ovaskainen et al. 2015) may also be useful 404 to cope with this challenge.

405 In sum, the performances of abundance models differed among species with intermediately406 common species typically fitted best. Natural environmental variables, particularly climate, appeared to 407 be most important for the abundance of individual species, but land use and spatial connections were 408 also strongly related to many species. Most fish species positively responded to the increase in percent 409 agricultural land in the watershed and the distance to dams/impoundments. There are multiple 410 challenges in accurately predicting species abundance, modeling remained to be a powerful tool for 411 resource management and aquatic ecology, and its utility will only improve over time as more robust 412 algorithms and high-resolution GIS habitat data, and more fish samples become available.

\section{Acknowledgements}

415 Authors are grateful to Tim Lambert for help with GIS mapping, to all field crew members who have 416 collected fish samples from IL streams, and to Bob Illyes who has managed the fish database in the 417 decades. This research was supported mainly by INHS General Revenue Fund, and supplemented by 418 Federal Aid in Sport Fish Restoration Project F-69-R.

\section{References}

421 Allan J.D. 2004. Landscapes and riverscapes: the influence of land use on stream ecosystems. Annu Rev $422 \quad$ Ecol Syst. 35: 257-284.

423 Allen, A.W., and Vandever, M.W. 2012. Conservation Reserve Program (CRP) contributions to wildlife 424 habitat, management issues, challenges and policy choices-an annotated bibliography: U.S. 425 Geological Survey Scientific Investigations Report 2012-5066, 185 p.

426 Andrewartha, H.G., and Birch, L.C. 1954. The distribution and abundance of animals. University of 427 Chicago Press.

428 Banks-Leite, C., Pardini, R., Boscolo, D., Cassano, C.R., Puttker, T., Barros, C.S. and Barlow, J. 2014. 429 Assessing the utility of statistical adjustments for imperfect detection in tropical conservation 430 science. J. Appl. Ecol. 51: 849-859. 
431 Barbet-Massin, M., Thuiller, W., and Jiguet, F. 2010. How much do we overestimate future local 432 extinction rates when restricting the range of occurrence data in climate suitability models? $433 \quad$ Ecography, 33: 878-886.

434 Bayley, P.B., Larimore, R.W. and Dowling, D.C. 1989. Electric seine as a fish-sampling gear in streams. T. $435 \quad$ Am. Fish. Soc. 118: 447-453.

436 Bayley, P.B., and Austen, D.J. 2002. Capture efficiency of a boat electrofisher. T. Am. Fish. Soc. 131:435$437 \quad 451$.

438 Beale, C.M., and Lennon, J.J. 2012. Incorporating uncertainty in predictive species distribution modelling. 439 Philosophical Transactions of the Royal Society B: Biological Sciences, 367: 247-258.

440 Blann, K.L., Anderson, J.L., Sands, G.R., and Vondracek, B. 2009. Effects of Agricultural Drainage on 441 Aquatic Ecosystems: A Review. Crit. Rev. Env. Sci. Tec. 39: 909-1001.

442 Brenden, T.O., Wang, L., Seelbach, P.W., Clark, R. D., Wiley, M.J., and Sparks-Jackson, B.L. 2006. A 443 spatially constrained clustering program for river valley segment delineation from GIS digital river 444 networks. Environ. Modell. Softw. 23: 638-649.

445 Breiman, L. 2001. Random forests. Machine Learning, 45: 5-32.

446 Breiman, L., Friedman, J., Stone, C. J. and Olshen, R. A. 1984. Classification and regression trees. CRC 447 press, New York.

448 Burkhead, N.M. 2012. Extinction rates in North America freshwater fishes, 1900-2010. Bioscience, 62 :

449 798-808.

450 Cao, Y., Stodola, A., Douglass, S., Shasteen, D., Cummings, K., Holtrop, A.M. 2015. Modeling and mapping the distribution, diversity, and abundance of freshwater mussels (Family Unionidae) in wadeable streams of Illinois, USA. Freshwater Biol. 60: 1379-1397.

Cutler, D.R., Edwards, T.C. Jr., Beard, K.H., Cutler, A., Hess, K.T., Gibson, J. and Lawler, J.J. 2007. Random forests for classification in ecology. Ecology, 88: 2783-2792.

Dormann, C.F., McPherson, J.M., Araújo, M.B., Bivand, R., Bolliger, J., Carl, G., Davies, R.G., Hirzel, A., Jetz, W., Kissling, W.D., Kuhn, I., Ohlemuller, R., Peres-Neto, P.R., Reieking, B., Schroder, B., Schurr, F.M., and Wilson, R. 2007. Methods to account for spatial autocorrelation in the analysis of species distributional data: a review. Ecography, 30: 609-628.

Dudgeon, D., Arthington, A. H., Gessner, M. O., Kawabata, Z. I., Knowler, D. J., Lévêque, C. and Sullivan, C. A. 2006. Freshwater biodiversity: importance, threats, status and conservation challenges. Biol. Rev. 81: 163-182. 
462 Elith, J., and Leathwick, J. 2009. Species distribution models: ecological explanation and prediction 463 across space and time. Annu. Rev Ecol. Syst. 40: 677-697.

464 Esselman, P.C., and Allan, J.D. 2010. Relative influences of catchment- and reach-scale abiotic factors on freshwater fish communities in rivers of northeastern Mesoamerica. Ecology of Freshwater Fish 19: 439-454.

Forbes, S. A. 1908. The fishes of Illinois. Illinois State Laboratory of Natural History.

Franklin, J., Wejnert, K.E., Hathaway, S.A., Rochester, C.J. and Fisher, R.N. 2009. Effect of species rarity on the accuracy of species distribution models for reptiles and amphibians in southern California. Diversity and Distribution, 15: 167-177.

Frederico, R.G., De Marco, Jr. P. and Zuanon, J. 2014. Evaluating the use of macroscale variables as proxies for local aquatic variables and to model stream fish distributions. Freshwater Biol. 59: 23032314.

Gaston, K. J., and McArdle, B. H. 1994. The temporal variability of animal abundances: measures, methods and patterns. Philos. T. Roy. Soc. B. 345: 335-358.

Godsoe, W., and Harmon, L.J. 2012. How do species interactions affect species distribution models. Ecography, 35: 811-820.

Grossman, G.D., Dowd, J.F., and Crawford, M. 1990. Assemblage stability in stream fishes: A review. Environmental Management, 14: 661-671.

Guillera-Arroita, G., Lahoz-Monfort, J.J., Mackenzie, D.I., Wintle, B.A., and McCarthy, M.A. 2014. Ignoring imperfect detection in biological surveys is dangerous: a response to "Fitting and Interpreting Occupancy Models". PLos One 9: e99571.

Harris, D.J. 2015. Generating realistic assemblages with a Joint Species Distribution Model. Methods in Ecology and Evolution (in press, DOI: 10.1111/2041-210X.12332).

Hinz Jr. L.C., Metzke, B.A. and Holtrop, A.M. 2011. Evaluating water temperature, habitat and fish communities in candidate coolwater streams in Illinois. Prepared for: Illinois Department of Natural Resources. State Wildlife Grant / Project Number (T-13-P-001). Illinois Natural History Survey Technical Report 2011 (21), Champaign, Illinois, USA.

Holtrop, A.M., Cao, Y., and Dolan, C.R. 2010. Estimating sampling effort required for characterizing species richness and site-to-site similarity in fish assemblage surveys of wadeable Illinois streams. T. Am. Fish. Soc. 139: 1421-1435. 
492 IL-EPA. 1996. Quality assurance and field methods manual for IDNR Division of Fisheries: IEPA basin

493 surveys in rivers and streams. Illinois Department of Environmental Protection, Bureau of Water, 494 Division of Water Pollution Control. Springfield, IL.

495 IL-DNR. 2010. Fisheries manual of operation: filed sampling protocols for rivers and streams. IL-DNR,

496 Division of Fisheries/Illinois Natural History Survey, 1816 S Oak Street, Champaign, IL 61820.

497 Iverson, L.R. 1989. Land use changes in Illinois, USA: the influence of landscape attributes on current

498 and historic land use. Landscape Ecology 2:45-61.

499 Johnson, D.H. 2008. In defense of indices: the case of bird surveys. J. Wildl. Manage. 72: 857-868.

500 Karpievitch, Y.V., Hill, E.G., Leclerc, A.P., Dabney, A.R. and Almeida, J. S. 2009. An introspective comparison of random forest-based classifiers for the analysis of cluster-correlated data by way of RF++. PLoS ONE 4, e7087.

Kuhn, M., and Johnson, K. 2013. Applied predictive models. Springer, New York, USA.

Larimore, R.W., and Smith, P.W. 1963. The fishes of Champaign County, Illinois as affected by 60 years of stream changes. Illinois Natural History Survey, Champaign, IL, USA.

Lawrence, D.J., Larsen, E.R., Liermann, C.A.R., Mims, M.C., Pool, T.K., and Olden, J.D. 2011. National parks as protected areas for US freshwater fish. Conserv. Lett. 4: 364-371.

Lyons, J., Stewart, J.S., and Mitro, M. 2010. Predicted effects of climate warming on the distribution of 50 stream fishes in Wisconsin, USA. J. Fish Biol. 77: 1867-1898.

McKenna, J.E., and Johnson, J.H. 2011. Landscape models of Brook trout abundance and distribution in lotic habitat with field validation. N. Am. J. Fish. Manage. 31: 742-756.

McKenna J.E., Carlson, D.M., and Payne-Wynne, M. 2013. Predicting locations of rare aquatic species' habitat with a combination of species-specific and assemblage-based models. Diversity and Distributions, 19: 503-517.

McPherson, J.M., and Jetz, W. 2007. Effects of species' ecology on the accuracy of distribution models. Ecography, 30: 135-151.

Moyle, P.B. and Herbold, B. 1987. Life-history patterns and community structure in stream fishes of Western North America: comparisons with eastern North America and Europe. In Community and Evolutionary Ecology of North American Stream Fishes (W.J. Matthews and D.C. Heins, eds.), pp. 2532. Norman, OK: University of Oklahoma Press. 
524 Newbold, T., Reader, T., Zalat, S., Ei-Gabbas, A., and Gilbert, F. 2009. Effect of characteristics of bufferfly 525 species on the accuracy of distribution models in an acrid environment. Biodivers. Conserv. 18: 3629-3641.

Nislow, K. H., Hudy, M., Letcher, B. H., and Smith, E. P. 2011. Variation in local abundance and species richness of stream fishes in relation to dispersal barriers: implications for management and conservation. Freshwater Biol. 56: 2135-2144.

Oakes, R.M., Gido, K.B., Falke, J.A., Olden, J.D., and Brock, B.L. 2005. Modeling of stream fishes in the Great Plains, USA. Ecol. Freshwater Fish, 14: 361-374.

Oberdorff, T., Pont, D., Hugueny, B., and Chessel, D. 2001. A probabilistic model characterizing fish assemblages of French rivers: a framework for environmental assessment. Freshwater Biol. 46: 399415.

Olden, J.D., Jackson, D.A., and Peres-Neto, P.R. 2002. Predictive models of fish species distributions: A note on proper validation and chance predictions. T. Am. Fish. Soc. 131: 329-336.

Ovaskainen, O., Roy, D.B., Fox, R., Anderson, B.J. 2015. Uncovering hidden spatial structure in species communities with spatially explicit joint species distribution models. Methods in Ecology and Evolution (in press, doi: 10.1111/2041-210X.12502).

Paul, M.J., and Meyer, J.L. 2001. Streams in the urban landscape. Annu. Rev. Ecol. Syst., 32:333-65

Peterson J. T., and Rabeni, C.F. 1995. Optimizing sampling effort for sampling warm water stream fish communities. North American Journal of Fisheries Management, 15: 528-541.

Peterson, A.T., Soberón, J., Pearson, R.G., Anderson, R.P., Martínez-Meyer, E., Nakamura, M., and Araújo, M.B. 2011. Ecological Niches and Geographic Distributions. Princeton University Press, Princeton, New Jersey, USA.

Pineda, E., Lobo, J.M. 2009. Assessing the accuracy of species distribution models to predict amphibian species richness patterns. Journal of Animal Ecology, 78: 172-180.

Price, A.L., and J. T. Peterson. 2010. Estimation and modeling of electrofishing capture efficiency for fishes in wadeable warmwater Streams. N. Am. J. Fish. Manage. 30:481-498.

Radinger, J. and Wolter, C. 2014. Patterns and predictors of fish dispersal in rivers. Fish and Fisheries, 15:

552 Richards, C., Johnson, L.B., and Host, G.E. 1996. Landscape-scale influences on stream habitats and biota. Can. J. Fish. Aquat. Sci. 53(suppl. 1): 295-311.

554 Royle, J.A., Kery, M., Goutier, R., and Smith, H. 2007. Hierarchical spatial models of abundance and 555 occurrence from imperfect survey data. Ecol. Monogr. 77: 465-481. 
Seelbach, P.W., Hinz, L.C., Wiley, M.J., and Cooper, A.R. 2010. Use of multiple linear regression to estimate flow regimes for all rivers across Illinois, Michigan, and Wisconsin. Research Report 2095, Fisheries Division, Michigan Department of Natural Resources and Environment, P.O. Box 30466, Lansing, MI 48909, USA.

Smith, P.W. 1979. The fishes of Illinois. University of Illinois Press, Urbana and Chicago, USA.

Smith, G.R., Badgley, C., Eiting, T.P., and Larson, P.S. 2010. Species diversity gradients in relation to geological history in North American freshwater fishes. Evol Ecol Res 12: 693-726.

Soininen, J., and Luoto, M. 2014. Predictability in species distributions: a global analysis across organisms and ecosystems. Global Ecol. Biogeogr. 23: 1264-1274.

Steen, P.J., Zorn, T.G., Seelbach, P.W., and Schaeffer, J.S. 2008. Classification tree models for predicting distributions of Michigan stream fish from landscape variables. T. Am. Fish. Soc. 137: 976-996.

Stoll, S., Sundermann, A., Lorenz, A.W., Kail, J., and Haase, P. 2013. Small and impoverished regional species pools constrain colonisation of restored river reaches by fishes. Freshwater Biol. 58: 664-674.

Stoll, S., Kail, J., Lorenz, A.W., Sundermann, A., and Haase, P. 2014. The importance of the regional species pool, ecological species traits and local habitat conditions for the colonization of restored river reaches by fish. PLOS ONE, 9(1), e84741.

Strayer, D. L. and Dudgeon, D. 2010. Freshwater biodiversity conservation: recent progress and future challenges. J. N. Am. Ben. Soc. 29: 344-358.

Stuart-Smith, R., Bates, A.E., Lefcheck, J., Duffy, E.J., Baker, S.C., Thomson, R., Stuart-Smith, J.F., Hill, N.A., Kininmonth, S.J., Airoldi, L., Becerro, M.A., Campbell, S.J.,Dawson, T.P., Navarrete, S.A., Soler, G., Strain, E.M.A., Willis, T.J., Edgar, G.J., 2013. Integrating abundance and functional traits reveals new global hotspots of fish diversity. Nature, 501: 539-542.

Tong, S.T.Y. and Chen, W.L. 2003. Modeling the relationship between land use and surface water quality. J. Environ. Manage. 66: 377-393.

Trainor, A.M., and Schmitz, O.J. 2014. Infusing considerations of trophic dependencies into species distribution modeling. Ecol. Lett. 17: 1507-1517.

Utz, R.M. 2014. Are we overlooking landscape-scale threats to common freshwater fishes? Fisheries, 39: 294-297.

Wang, L.Z., Lyons, J., Kanehl, P., Bannerman, R., and Emmons, E. 2000. Watershed urbanization and changes in fish communities in southern Wisconsin streams. J. Am. Water Resour. As. 36: 1173-1189. 
586 Wang, L.Z., Infante, D., Lyons, J., Stewart, J., and Cooper, A. 2011. Effects of dams in river networks on 587 fish assemblages in non-impoundment section of rivers in Michigan and Wisconsin, USA. River Res. 588 Appl. 27: 473-487.

589 Welch, A.H., Lindenmayer, D.B., and Donnelly, C.F. 2013. Fitting and interpreting occupancy models. $590 \quad$ PLoS One 8: e52015.

591 Wenger, S.J., and Freeman, M.C. 2008. Estimating species occurrence, abundance, and detection 592 probability using zero-inflated distributions. Ecology, 89: 2953-2959. 
Table 1. Random-forests regression models for 97 fish species that were recorded at $>10$ reaches in small wadeable streams $(\leq 18 \mathrm{~m})$ in Illinois, USA, and the importance of different types of environmental variables for 50 species with $R^{2} \geq 0.2$, measured with the number of variables ranking a type in the top 10 predictors and the highest rank (in parentheses) $(\mathrm{N}=$ number of sites where a species was recorded; $\mathrm{mtry}=$ the number of variables used for a split, $\mathrm{Clim}=$ climate, $\mathrm{Con}=$ connection, $\mathrm{LU}=$ land use, $\mathrm{SS}=$ stream size, Soil = soil permeability, Geo= geology, Top = topography, also see Appendix 2).

\begin{tabular}{|c|c|c|c|c|c|c|c|c|c|c|c|}
\hline Scientific Name & Common Name & $\mathrm{N}$ & $R^{2}$ & mtry & Clim & Con & LU & Soil & $\mathrm{SS}$ & Geo & Top \\
\hline \multicolumn{12}{|l|}{ Amiidae (1) } \\
\hline Amia calva & Bowfin & 33 & 0.08 & 3 & & & & & & & \\
\hline \multicolumn{12}{|l|}{ Aphredoderidae (1) } \\
\hline Aphredoderus sayanus & Pirate perch & 189 & 0.42 & 4 & $3(1)$ & & $1(8)$ & $2(4)$ & & $2(6)$ & $2(9)$ \\
\hline \multicolumn{12}{|l|}{ Atherinidae } \\
\hline Labidesthes sicculus & Brook silverside & 12 & 0.05 & 2 & & & & & & & \\
\hline \multicolumn{12}{|l|}{ Catostomidae (15) } \\
\hline Carpiodes carpio & River carpsucker & 129 & 0.17 & 3 & & & & & & & \\
\hline Carpiodes cyprinus & Quillback & 228 & 0.22 & 4 & $3(1)$ & & $2(5)$ & & $2(2)$ & $1(6)$ & $2(4)$ \\
\hline Carpiodes velifer & Highfin carpsucker & 45 & 0.07 & 2 & & & & & & & \\
\hline Catostomus commersonii & White sucker & 542 & 0.33 & 5 & $3(2)$ & & $3(6)$ & & $2(1)$ & $1(9)$ & $1(4)$ \\
\hline Erimyzon oblongus & Creek chubsucker & 181 & 0.38 & 5 & $3(1)$ & $1(7)$ & $1(5)$ & $4(4)$ & & $1(10)$ & \\
\hline Hypentelium nigricans* & Northern hog sucker & 209 & 0.40 & 6 & $3(1)$ & $1(4)$ & $2(6)$ & & & $3(3)$ & $1(10)$ \\
\hline Ictiobus bubalus & Smallmouth buffalo & 52 & 0.02 & 2 & & & & & & & \\
\hline Ictiobus cyprinellus & Bigmouth buffalo & 63 & 0.02 & 2 & & & & & & & \\
\hline Ictiobus niger & Black buffalo & 18 & 0.00 & 2 & & & & & & & \\
\hline Minytrema melanops & Spotted sucker & 108 & 0.11 & 3 & & & & & & & \\
\hline Moxostoma anisurum & Silver redhorse & 85 & 0.14 & 2 & & & & & & & \\
\hline Moxostoma duquesnei & Black redhorse & 65 & 0.25 & 4 & $2(1)$ & $1(5)$ & $3(3)$ & $1(10)$ & $2(7)$ & $1(8)$ & \\
\hline Moxostoma erythrurum & Golden redhorse & 346 & 0.33 & 5 & $3(1)$ & $1(6)$ & $2(5)$ & $1(4)$ & $2(7)$ & $1(8)$ & \\
\hline Moxostoma macrolepidotum & Shorthead redhorse & 213 & 0.21 & 4 & $3(1)$ & $1(4)$ & $1(8)$ & & $2(5)$ & $1(10)$ & $2(6)$ \\
\hline \multicolumn{12}{|l|}{ Centrarchidae (14) } \\
\hline Ambloplites rupestris & Rock bass & 126 & 0.37 & 5 & $3(2)$ & $2(1)$ & $1(8)$ & $1(10)$ & & $2(6)$ & $1(3)$ \\
\hline Centrarchus macropterus & Flier & 25 & 0.12 & 2 & & & & & & & \\
\hline Lepomis cyanellus & Green sunfish & 626 & 0.25 & 6 & $3(1)$ & $3(7)$ & $2(6)$ & $2(2)$ & & & \\
\hline Lepomis gibbosus & Pumpkinseed & 14 & 0.23 & 5 & $3(3)$ & $3(1)$ & $1(9)$ & $1(2)$ & & $2(7)$ & \\
\hline Lepomis gulosus & Warmouth & 85 & 0.31 & 5 & $3(1)$ & & $2(8)$ & $2(2)$ & & $1(5)$ & $2(6)$ \\
\hline Lepomis humilis & Orangespotted sunfish & 152 & 0.15 & 5 & & & & & & & \\
\hline Lepomis macrochirus & Bluegill & 555 & 0.26 & 4 & $3(1)$ & & $2(4)$ & $2(8)$ & & $2(7)$ & $1(5)$ \\
\hline Lepomis megalotis & Longear sunfish & 356 & 0.51 & 5 & $3(1)$ & & $2(7)$ & $2(5)$ & & $2(9)$ & $1(3)$ \\
\hline Lepomis microlophus & Redear sunfish & 73 & 0.05 & 2 & & & & & & & \\
\hline Micropterus dolomieu & Smallmouth bass & 221 & 0.42 & 5 & $3(1)$ & $3(4)$ & $1(8)$ & $1(9)$ & & $2(6)$ & \\
\hline Micropterus punctulatus & Spotted bass & 65 & 0.18 & 4 & & & & & & & \\
\hline Micropterus salmoides & Largemouth bass & 515 & 0.12 & 5 & & & & & & & \\
\hline Pomoxis annularis & White crappie & 80 & 0.10 & 2 & & & & & & & \\
\hline Pomoxis nigromaculatus & Black crappie & 85 & 0.01 & 2 & & & & & & & \\
\hline
\end{tabular}




\begin{tabular}{|c|c|c|c|c|c|c|c|c|c|c|c|}
\hline \multicolumn{12}{|l|}{ Clupeidae (1) } \\
\hline Dorosoma cepedianum & Gizzard shad & 275 & 0.18 & 4 & & & & & & & \\
\hline \multicolumn{12}{|l|}{ Cottidae (1) } \\
\hline \multicolumn{12}{|l|}{ Cyprinidae (30) } \\
\hline Campostoma anomalum & Central stoneroller & 504 & 0.48 & 6 & $3(2)$ & & 1(6) & 2(3) & 1(9) & $1(10)$ & $2(1)$ \\
\hline Campostoma oligolepis & Largescale stoneroller & 38 & 0.36 & 6 & $3(2)$ & 1(5) & $2(6)$ & 1(7) & & $3(1)$ & \\
\hline Carassius auratus & Goldfish & 16 & 0.08 & 2 & & & & & & & \\
\hline Ctenopharyngodon idella & Grass carp & 27 & 0.00 & 2 & & & & & & & \\
\hline Cyprinella lutrensis & Red shiner & 353 & 0.47 & 6 & 3(1) & 1(7) & $1(9)$ & 2(4) & & $2(8)$ & $1(3)$ \\
\hline Cyprinella spiloptera & Spotfin shiner & 214 & 0.38 & 6 & $3(1)$ & $1(10)$ & 1(9) & 2(4) & & $3(6)$ & \\
\hline Cyprinella whipplei & Steelcolor shiner & 88 & 0.41 & 8 & $3(1)$ & & 4(3) & & $1(7)$ & $2(2)$ & \\
\hline Cyprinus carpio & Common carp & 390 & 0.11 & 3 & & & & & & & \\
\hline Hybognathus nuchalis & Silvery minnow & 62 & 0.13 & 3 & & & & & & & \\
\hline Luxilus chrysocephalus & Striped shiner & 284 & 0.57 & 6 & $3(2)$ & $2(1)$ & $2(5)$ & & & $2(6)$ & $1(8)$ \\
\hline Luxilus cornutus* & Common shiner & 87 & 0.58 & 7 & $3(1)$ & & 2(4) & $2(5)$ & $1(10)$ & $2(6)$ & \\
\hline Lythrurus fumeus & Ribbon shiner & 31 & 0.12 & 2 & & & & & & & \\
\hline Lythrurus umbratilus & Redfin shiner & 414 & 0.28 & 5 & $3(2)$ & & $2(1)$ & $3(4)$ & & 1(7) & $1(6)$ \\
\hline Nocomis biguttatus* & Hornyhead chub & 326 & 0.57 & 6 & $3(1)$ & $3(4)$ & $3(6)$ & $1(10)$ & & & \\
\hline Notemigonus crysoleucas & Golden shiner & 174 & 0.22 & 6 & $3(1)$ & $1(10)$ & 2(6) & $2(4)$ & & 2(3) & \\
\hline Notropis atherinoides & Emerald shiner & 102 & 0.16 & 3 & & & & & & & \\
\hline Notropus blennius & River Shiner & 13 & 0.05 & 2 & & & & & & & \\
\hline Notropis boops & Bigeye shiner & 13 & 0.35 & 4 & & & 2(2) & $2(1)$ & $3(7)$ & $1(10)$ & $2(3)$ \\
\hline Notropis buccatus & Silverjaw minnow & 132 & 0.43 & 8 & $3(1)$ & & $1(10)$ & 2(3) & & $2(7)$ & $2(4)$ \\
\hline Notropis dorsalis & Bigmouth shiner & 245 & 0.35 & 6 & $3(1)$ & & $2(5)$ & $2(6)$ & & 1(8) & $2(2)$ \\
\hline Notropis nubilus & Ozark minnow & 14 & 0.50 & 5 & $3(1)$ & & $3(5)$ & $1(10)$ & & $3(2)$ & \\
\hline Notropis percobromus & Carmine shiner & 80 & 0.34 & 7 & $3(2)$ & 1(1) & 1(7) & 1(9) & & $4(5)$ & \\
\hline Notropis stramineus $*$ & Sand shiner & 441 & 0.40 & 6 & $3(1)$ & $1(8)$ & 2(3) & $2(5)$ & & 1(9) & 1(6) \\
\hline Phenacobius mirabilis & Suckermouth minnow & 316 & 0.24 & 6 & $3(4)$ & 1(9) & 2(3) & & $1(8)$ & $1(10)$ & $2(1)$ \\
\hline Phoxinus erythrogaster & Southern redbelly dace & 56 & 0.18 & 3 & & & & & & & \\
\hline Pimephales notatus & Bluntnose minnow & 648 & 0.22 & 4 & $2(1)$ & & $1(6)$ & $2(5)$ & $2(3)$ & $1(4)$ & $2(8)$ \\
\hline Pimephales promelas & Fathead minnow & 126 & 0.11 & 2 & & & & & & & \\
\hline Pimephales vigilax & Bullhead minnow & 78 & 0.20 & 7 & $3(3)$ & & 2(4) & 2(7) & $3(1)$ & & \\
\hline Rhinichthys atratulus & Blacknose dace & 84 & 0.21 & 5 & $3(1)$ & & $3(7)$ & 1(6) & & 1(9) & $2(2)$ \\
\hline Semotilus atromaculatus & Creek chub & 528 & 0.30 & 6 & $3(3)$ & & 1(7) & & $4(1)$ & & 2(4) \\
\hline \multicolumn{12}{|l|}{ Esocidae (2) } \\
\hline Esox americanus & Grass pickerel & 187 & 0.29 & 6 & 2(1) & & 2(3) & 2(2) & & $1(4)$ & $3(5)$ \\
\hline Esox Lucius & Northern pike & 25 & 0.13 & 3 & & & & & & & \\
\hline \multicolumn{12}{|l|}{ Fundulidae (2) } \\
\hline Fundulus notatus & Blackstripe topminnow & 393 & 0.31 & 4 & $3(1)$ & & $3(6)$ & 2(4) & & & 2(7) \\
\hline Fundulus olivaceus & Blackspotted topminnow & 105 & 0.70 & 5 & $3(1)$ & $1(10)$ & $2(3)$ & & & $3(7)$ & 1(6) \\
\hline
\end{tabular}


Table 1 continues

\begin{tabular}{|c|c|c|c|c|c|c|c|c|c|c|c|}
\hline \multicolumn{12}{|l|}{ Gasterosteidae (1) } \\
\hline Culaea inconstans & Brook stickleback & 12 & 0.05 & 2 & & & & & & & \\
\hline \multicolumn{12}{|l|}{ Ictaluridae (9) } \\
\hline Ameiurus melas & Black bullhead & 112 & 0.13 & 2 & & & & & & & \\
\hline Ameiurus natalis & Yellow bullhead & 497 & 0.14 & 5 & & & & & & & \\
\hline Ictalurus punctatus & Channel catfish & 244 & 0.22 & 3 & $2(8)$ & & $2(4)$ & & $4(1)$ & $1(6)$ & $1(5)$ \\
\hline Noturus exilis & Slender madtom & 44 & 0.12 & 4 & & & & & & & \\
\hline Noturus flavus* & Stonecat & 166 & 0.24 & 5 & $3(1)$ & $1(8)$ & $2(6)$ & $1(9)$ & & $1(10)$ & $2(4)$ \\
\hline Noturus gyrinus & Tadpole madtom & 142 & 0.11 & 2 & & & & & & & \\
\hline Noturus miurus & Brindled madtom & 30 & 0.22 & 4 & $3(1)$ & $1(8)$ & $2(7)$ & $1(4)$ & & $2(3)$ & $1(6)$ \\
\hline Noturus nocturnus & Freckled madtom & 37 & 0.07 & 2 & & & & & & & \\
\hline Pylodictis olivaris & Flathead catfish & 40 & 0.10 & 2 & & & & & & & \\
\hline \multicolumn{12}{|l|}{ Lepisosteidae (2) } \\
\hline Lepisosteus osseus & Longnose gar & 17 & 0.00 & 2 & & & & & & & \\
\hline Lepisosteus platostomus & Shortnose gar & 45 & 0.02 & 2 & & & & & & & \\
\hline \multicolumn{12}{|l|}{ Moronidae (2) } \\
\hline Morone chrysops & White bass & 21 & 0.04 & 2 & & & & & & & \\
\hline Morone mississippiensis & Yellow bass & 12 & 0.02 & 2 & & & & & & & \\
\hline \multicolumn{12}{|l|}{ Percidae (13) } \\
\hline Etheostoma asprigene & Mud darter & 32 & 0.00 & 2 & & & & & & & \\
\hline Etheostoma blennioides & Greenside darter & 44 & 0.37 & 7 & $3(1)$ & $2(2)$ & $1(3)$ & $1(7)$ & & $2(9)$ & $1(5)$ \\
\hline Etheostoma caeruleum & Rainbow darter & 74 & 0.18 & 5 & & & & & & & \\
\hline Etheostoma chlorosomum & Bluntenose darter & 20 & 0.01 & 2 & & & & & & & \\
\hline Etheostoma flabellare & Fantail darter & 175 & 0.37 & 5 & $3(1)$ & & $1(10)$ & $2(5)$ & & $3(6)$ & $1(4)$ \\
\hline Etheostoma nigrum* & Johnny darter & 422 & 0.25 & 4 & $3(1)$ & $1(6)$ & $2(4)$ & $2(8)$ & & $1(9)$ & $1(7)$ \\
\hline Etheostoma spectabile & Orangethroat darter & 245 & 0.28 & 5 & $3(2)$ & & $1(8)$ & $2(4)$ & $1(9)$ & & $3(1)$ \\
\hline Etheostoma zonale & Banded darter & 97 & 0.37 & 6 & $2(1)$ & $1(6)$ & $1(9)$ & $2(7)$ & & $3(2)$ & $1(5)$ \\
\hline Percina caprodes & Logperch & 86 & 0.08 & 2 & & & & & & & \\
\hline Percina maculate & Blackside darter & 228 & 0.22 & 5 & $3(4)$ & $3(1)$ & $1(10)$ & $2(2)$ & & & $1(9)$ \\
\hline Percina phoxocephala & Slenderhead darter & 109 & 0.18 & 5 & & & & & & & \\
\hline Percina sciera & Dusky darter & 28 & 0.05 & 2 & & & & & & & \\
\hline Stizostedion vitreum & Walleye & 20 & 0.04 & 3 & & & & & & & \\
\hline \multicolumn{12}{|l|}{ Poeciliidae (1) } \\
\hline Gambusia affinis & Mosquitofish & 171 & 0.21 & 6 & $3(1)$ & & $2(4)$ & & & $2(6)$ & $3(5)$ \\
\hline \multicolumn{12}{|l|}{ Sciaenidae (1) } \\
\hline Aplodinotus grunniens & Freshwater drum & 131 & 0.12 & 3 & & & & & & & \\
\hline \multicolumn{12}{|l|}{ Umbridae (1) } \\
\hline Umbra limi & Central mudminnow & 19 & 0.10 & 2 & & & & & & & \\
\hline $\begin{array}{l}\text { Number of species ranking the } \\
\text { or top } 3 \text { predictors (\# top 10/\# }\end{array}$ & of variables as top 10 & & & & $49 / 43$ & $25 / 6$ & $50 / 10$ & $39 / 7$ & $17 / 7$ & $42 / 7$ & $35 / 10$ \\
\hline
\end{tabular}

* species used for assessing modeling uncertainty. 
Table 2. Twenty-eight fish species recorded in $\geq 5$ reaches collected from Kaskaskia River Basin, Illinois, and the Spearman correlations between their observed (Obs) and predicted abundances (log-transformed) (Pred) $(N=$ number of samples where a species was recorded, average $=$ number of individuals per sample, $\mathrm{SD}=$ standard deviation, $* p<0.05$ ).

\begin{tabular}{|c|c|c|c|c|c|}
\hline Common Name & $N$ & Average & SD & $\begin{array}{r}\text { Spearman r } \\
\text { for Obs-Pred }\end{array}$ & Model $R^{2}$ \\
\hline Bigmouth shiner & 35 & 32.8 & 103.8 & $0.41^{*}$ & 0.35 \\
\hline Blackside darter & 17 & 0.5 & 2.0 & $0.48^{*}$ & 0.22 \\
\hline Bluegill & 72 & 20.8 & 43.5 & $0.47 *$ & 0.26 \\
\hline Bluntnose minnow & 86 & 77.4 & 221.1 & $0.51 *$ & 0.22 \\
\hline Blackstripe topminnow & 74 & 30.3 & 148.5 & $0.26^{*}$ & 0.31 \\
\hline Bullhead minnow & 4 & 0.4 & 2.7 & 0.00 & 0.20 \\
\hline Chanel catfish & 4 & 0.5 & 4.1 & $0.57 *$ & 0.22 \\
\hline Central stoneroller & 72 & 78.3 & 187.9 & $0.40^{*}$ & 0.48 \\
\hline Creek chub & 92 & 140 & 317.1 & $0.34 *$ & 0.30 \\
\hline Creek chubsucker & 43 & 10.6 & 39.9 & $0.41 *$ & 0.38 \\
\hline Golden redhorse & 6 & 0.90 & 5.8 & $0.26^{*}$ & 0.30 \\
\hline Golden shiner & 16 & 1.0 & 3.8 & 0.00 & 0.22 \\
\hline Green sunfish & 99 & 44.9 & 106.0 & $0.26^{*}$ & 0.25 \\
\hline Grass pickerel & 16 & 2.3 & 9.8 & $0.63^{*}$ & 0.29 \\
\hline Hornyhead chub & 13 & 1.6 & 6.7 & $0.56^{*}$ & 0.57 \\
\hline Johnny darter & 70 & 24.8 & 46.0 & $0.31 *$ & 0.25 \\
\hline Longear sunfish & 38 & 4.6 & 10.5 & $0.30^{*}$ & 0.51 \\
\hline Orangethroat darter & 29 & 10.9 & 49.6 & 0.00 & 0.28 \\
\hline Quillback & 5 & 0.4 & 3.3 & $0.43 *$ & 0.22 \\
\hline Pirate perch & 39 & 21.0 & 60.7 & $0.54^{*}$ & 0.42 \\
\hline Redfin shiner & 41 & 8.6 & 21.0 & $0.24 *$ & 0.28 \\
\hline Red shiner & 71 & 67.1 & 220.2 & $0.50^{*}$ & 0.47 \\
\hline Sand shiner & 56 & 60.6 & 153.8 & $0.36^{*}$ & 0.40 \\
\hline Silverjaw minnow & 47 & 31.3 & 77.9 & $0.57 *$ & 0.43 \\
\hline Striped shiner & 13 & 1.4 & 4.9 & $0.52 *$ & 0.57 \\
\hline Suckermouth minnow & 38 & 8.8 & 24.7 & $0.39 *$ & 0.24 \\
\hline White sucker & 55 & 12.4 & 31.1 & $0.23 *$ & 0.33 \\
\hline Max & 99 & 164 & 317.1 & 0.57 & 0.57 \\
\hline Min & 4 & 0.4 & 2.0 & 0.00 & 0.20 \\
\hline Average & 43 & 26.8 & 71.7 & 0.37 & 0.35 \\
\hline
\end{tabular}




\section{Captions}

Fig. 1. Locations of 701 fish sampling sites in wadeable streams of Illinois, USA with bold boundary for Kaskaskia River Basin where validation samples were collected (HUC8 = US-GS Hydrological Unit Code 8).

Fig. 2. Correlations between $R^{2}$-values in RF regression and species prevalence (number of sites where a species was recorded) (dotted line is a polynomial fitting).

Fig. 3. Spatial pattern in the number of fish individuals for central stoneroller (left) and smallmouth bass (right) per $1000 \mathrm{~m}^{2}$ across wadeable streams with wet-channel width $\leq 18 \mathrm{~m}$ in Illinois, USA, based on random-forests model predictions (NA = not applicable water bodies, mainly lakes, large rivers, and wide streams). The local watershed (see definition in text) of a stream reach is mapped.

Fig. 4. Example partial-dependence plots of random-forests regression showing the relationships between log-transformed species abundance (y-axes) and different environmental variables (as described in Appendix 2) (x-axis with the observed range highlighted) with Panel a: WT_GDD = average growing-degree-day in the total watershed, b) Damdn_L = distance (km) from a downstream dam, c) WT_Agri = proportion of agricultural land in the total watershed, d) WT_Perm = average soil permeability in the total watershed, e) BR50 = bedrock depth $\leq 50$ feet, and f) WP_Slope = average slope of the total watershed; species are labelled as follows: BLG = Bluegill, CMS = Common shiner, FAD $=$ Fantail darter, GOS = Golden shiner, GSF = Green sunfish, HOC $=$ Hornyhead chub, LOS $=$ Longear sunfish, NHS = Northern hogsucker, PRP = Pirate perch, RDS = Redfin shiner, SFS = Spotfin shiner, SHR = Shorthead redhorse, $\mathrm{SMB}=$ Smallmouth bass, STS = Striped shiner (Y2 = the second $\mathrm{y}$-axis $)$. 


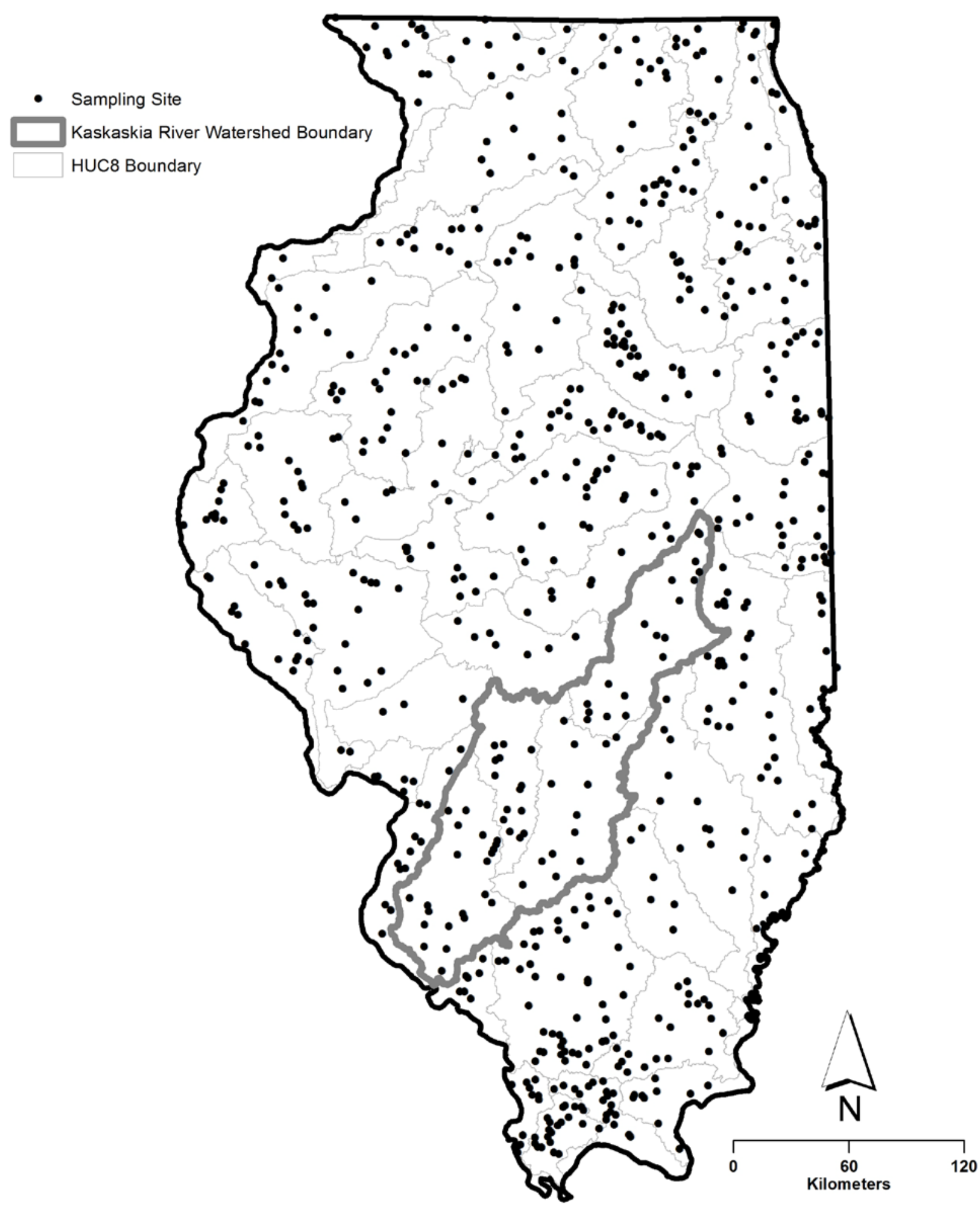

Fig. 1 


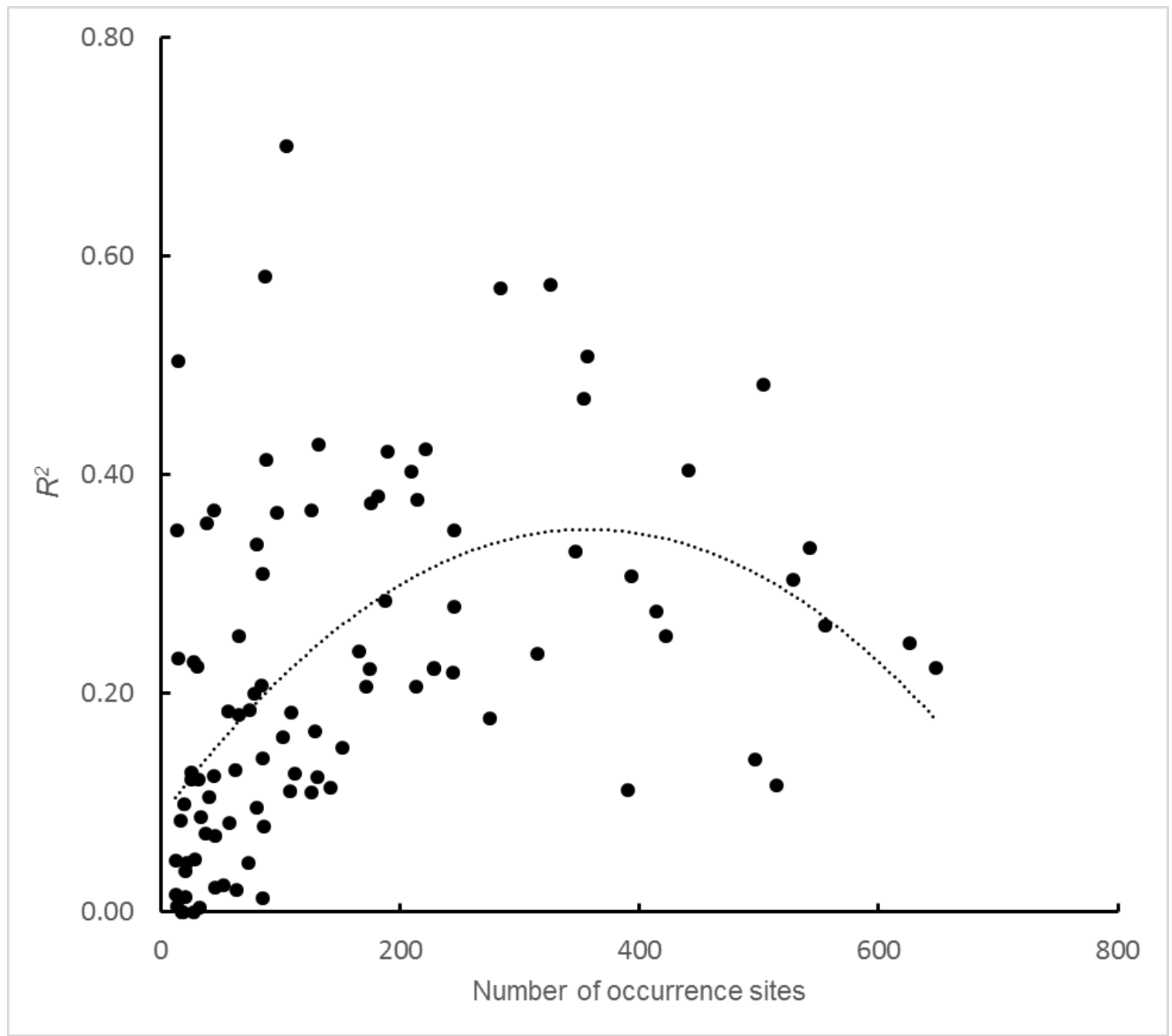

Fig. 2 

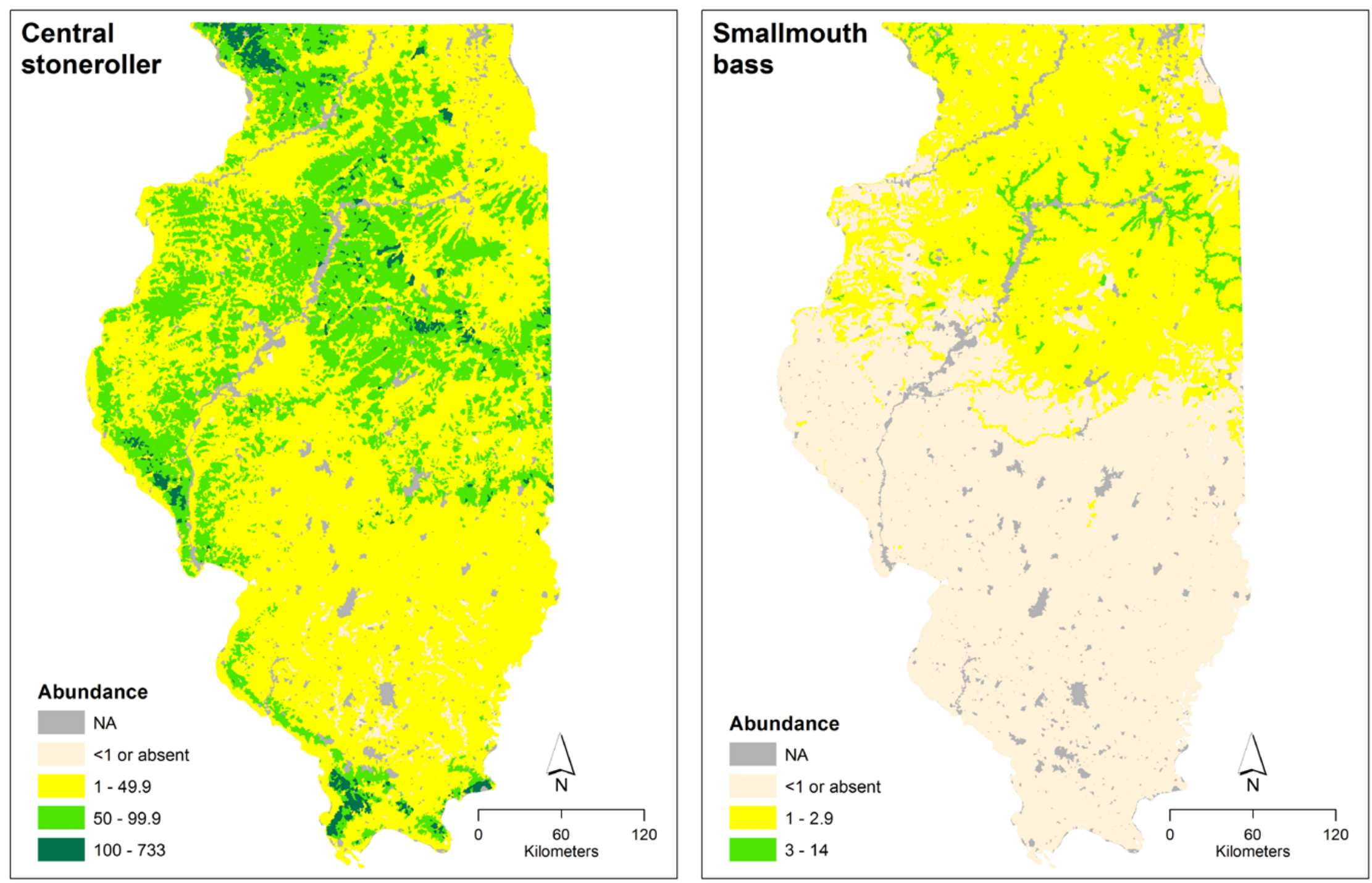

Fig. 3 

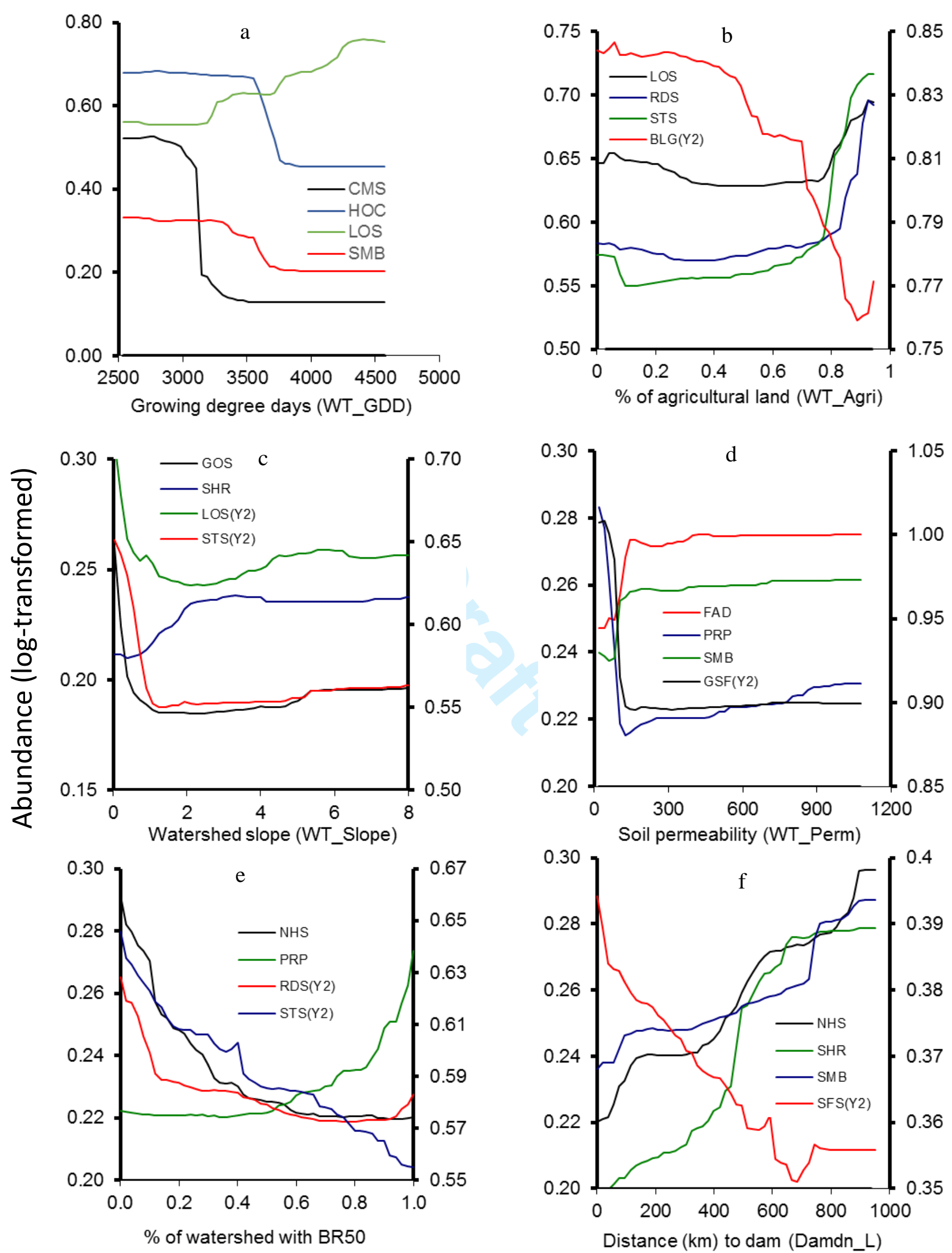

Fig. 4 
Appendix 1. Overview of 70 stream/lake fish modeling studies published in peer-reviewed journals during 2000-2015 (Den = density; DC = density class; PA = presence-absence). Web of Science and Google Scholar were used for search with the combinations of several terms as key words: freshwater, stream, river, fish, habitat/niche/distribution model, climate changes, and land use.

\begin{tabular}{|c|c|c|c|c|c|c|c|c|}
\hline Authors & Journal & Year & Species & \# of Sites & Study Area & Country & Type & Predictors \\
\hline Porter et al. & N. Am. J. Fish Manage. & 2000 & 13 & 48 & Blackwater R. Basin (BC) & Canada & PA & habitats \& watershed \\
\hline Oberdorff et al. & Freshwater Biol. & 2001 & 34 & 650 & Nation-wide & France & PA & climate, habitats, watershed \\
\hline Olden \& Jackson & Freshwater Biol. & 2002 & 27 & 286 & Algonquin Park (ON) & Canada & PA & lake-local habitat \\
\hline \multirow{2}{*}{ Olden et al. } & T. Am. Fish. Soc. & 2002 & 14 & 48 & Blackwater R. Basin (BC) & Canada & PA & watershed \\
\hline & T. Am. Fish. Soc. & 2002 & 26 & 89 & Petawawa R. Basin (ON) & Canada & PA & lake morphology; \\
\hline Argent et al. & Fish Res & 2003 & 153 & NA & State-wide (PA) & USA & PA & watershed basin variables (GIS) \\
\hline Dominguez et al. & Conserv Biol & 2005 & 41 & 551 & Central Mexcico & Mexico & PA & Climate \& topography (GIS) \\
\hline Leathwick et al. & Freswater Biol. & 2005 & 15 & $9866^{\wedge}$ & Nation-wide & New Zealand & PA & watershed/reach GIS \\
\hline McNyset & Ecol Freshw. Fish & 2005 & 12 & $38-141^{*}$ & State-wide (KS) & USA & PA & Landscape_GIS \\
\hline Oakes et al. & Ecol Freshw. Fish & 2005 & 38 & 120 & Big Blue R. Basin & USA & PA & Watershed-GIS \\
\hline Rashleigh et al. & N. Am. J. Fish. Manage. & 2005 & 13 & 264 & Mid-Atlantic Highland & USA & PA & local habitats \\
\hline Chessman & Mar. Freshwater Res. & 2006 & 54 & 85 & New South Wales & Australia & PA & Watershed size \& Altitude (GIS) \\
\hline Gido et al. & AFS Symposium & 2006 & 41 & 150 & Lower Kansas R. Basin & USA & PA & Landscape_GIS \\
\hline Ruiz \& Peterson & T. Am. Fish. Soc. & 2007 & 46 & 257 & Flint R. Basin & USA & PA & Landscape-GIS \\
\hline Buisson et al. & Ecol Freshw. Fish. & 2008 & 28 & 141 & Adour-Garonne Basin & France & PA & watershed \& habitat \\
\hline Dauwalter \& Rahel & Aquatic. Conserv. & 2008 & 1 & 289 & Black Hill Forest & USA & PA & Landscape_GIS \\
\hline Lassalle et al. & Freshwater Biol. & 2008 & 28 & 136 (basins) & Europe & Europe & PA & Landscape_GIS \\
\hline McCleary \& Hassan & Can. J. Fish. Aquat. Sci. & 2008 & 3 & 692 & Rocky Mountains & Canada & PA & habitat \& landuse \\
\hline Sharma \& Jackson & Can. J. Fish. Aquat. Sci. & 2008 & 1 & $4181^{\wedge}$ & North America & North America & PA & Climate-GIS \\
\hline Wenger et al. & Can. J. Fish. Aquat. Sci. & 2008 & 5 & $357^{\wedge}$ & Etowah R. Basin (GA) & USA & PA & local, historic \& current land use \\
\hline Essekman \& Allan & Freshwater Biol. & 2010 & 63 & 303 & Belize Coast & Belize & PA & watershed-GIS \\
\hline Lyons et al. & J. Fish. Biol. & 2010 & 50 & 282 & State-wide (WI) & USA & PA & watershed-GIS \\
\hline Grenouillet et al. & Ecography & 2011 & 35 & 1110 & Nation-wide & France & PA & climate, habitats, watershed \\
\hline Anderson et al & T. Am. Fish. Soc & 2012 & 1 & 40 & Etowah R. Basin (GA) & USA & PA & local habitats \& watershed \\
\hline Groce et al. & T. Am. Fish. Soc & 2012 & 1 & 19 & Arkansars R. Basin (CO) & USA & PA & local habitats \\
\hline Logez et al. & Ecol Freshw. Fish & 2012 & 21 & 1548 & 14 countries & Europe & PA & flow, Temp \& watershed size \\
\hline Markovic et al. & PLOS One & 2012 & 38 & & Nation-wide & Germany & PA & GIS (climate, hydrology, topography) \\
\hline Michel \& Knouft & PLOS One & 2012 & 5 & 1 & one stream (MO) & USA & PA & Habitats \\
\hline Mouton et al. & Ecol Model & 2012 & 1 & 1 & River Grote Nete & Belgium & PA & local habitats \\
\hline Richardo et al. & Freshwater Biol. & 2012 & 4 & 167 & Amazon R. Basin & Brazil & PA & GIS (Landscape) \\
\hline Sindt et al. & N. Am. J. Fish. Manage & 2012 & 10 & 86 & Mississippi R. Basin (IA) & USA & PA & watershed_GIS \\
\hline Zarkami et al. & Ecol Model & 2012 & 1 & 75 & Flanders & Belgium & PA & local habitat, WQ, \\
\hline Albanese et al. & Ecol Freshw. Fish & 2013 & 1 & 115 & Coosawatee R. Basin (GA) & USA & PA & watershed \& habitats \\
\hline Black et al. & SE Naturalist & 2013 & 1 & 72 & Upper Cumberland R Basin & USA & PA & local habitats \\
\hline Comte \& Grenouillet & Diversity \& Distribution & 2013 & 35 & 839 & Nation-wide & France & PA & climate \& watershed (GIS) \\
\hline Filipe et al. & Diversity Distrib & 2013 & 1 & 3843 & 3 EU basins & Europe & PA & GIS (climate, landuse) \\
\hline Hopkins \& Roush & Ecol Freshw. Fish & 2013 & 6 & $239^{\wedge}$ & Upper Kentucky R Basin & USA & PA & Landscape GIS \\
\hline Nowosad \& Taylor & Can. J. Zool. & 2013 & 1 & 60 & Lower Fraser R. & Canada & PA & local habitat \& fish \\
\hline
\end{tabular}

Appendix 1 continued 


\begin{tabular}{|c|c|c|c|c|c|c|c|c|}
\hline Authors & Journal & Year & Species & \# of Sites & Study Area & Country & Type & Predictors \\
\hline Ptolemy & N. Am. J. Fish. Manage & 2013 & 2 & 649 & $\mathrm{BC}$ and West-coastal US & US \& Canada & PA & habitats \& watershed \\
\hline Wuellner et al. & J. Fish. Biol. & 2013 & 20 & 120 & Great Plains (MT) & USA & PA & local habitat \& watershed \\
\hline Dextrase et al. & Freshwater Biol. & 2014 & 2 & 151 & Grand \& Thames R. Basin $(\mathrm{ON})$ & Canada & PA & Local habitat \& Watershed \\
\hline Frederico et al & Freshwater Biol. & 2014 & 6 & 380 & Amazon R. Basin & Brazil & PA & climate,soil, \& veg. (GIS) \\
\hline Grenouillet \& Comte & Global Change Biology & 2014 & 32 & 3549 & Nation wide & France & PA & climate, habitats, watershed \\
\hline Lauzeral et al. & Ecography & 2014 & 31 & 1110 & National- wide & France & PA & Watershed and habitat \\
\hline Shea et al. & River Res. Appl. & 2014 & 15 & 6 & Elk R. Basin (TN,AL) & USA & PA & flow \& temperature \\
\hline Vezza et al. & Aquat. Sci. & 2014 & 1 & 95 & Alps & Italy & PA & local habitats \\
\hline Yoshihiro et al. & Popul Ecol. & 2014 & 2 & 48 & Two streams (Central Brazil) & Brazil & PA & flow \\
\hline Askeyev et al. & Environ Biol Fish & 2015 & 26 & 245 & Nation wide & Tartarstan & PA & Local habitat, Elevation \\
\hline Bouska et al. & Hydrobiologia & 2015 & 14 & 12 & Midwest states & USA & PA & GIS (Geo,landuse, climate) \\
\hline Clavero1 \& Hermoso & J. Appl. Ecol. & 2015 & 1 & 5427 & Nation-wide & Span & PA & Topography, distance to sea \\
\hline Comte \& Grenouillet & Diversity \& Distribution & 2015 & 16 & 3627 & Nation-wide & France & PA & Climate, topography \\
\hline Guo et al. & Ecol. Model. & 2015 & 92 & 135 & Nation-wide lakes & China & PA & Climate, lake location, size \\
\hline Kanno et al. & T. Am. Fish. Soc. & 2015 & 1 & 559 & State-wide (CT) & USA & PA & GIS (Geo,landuse, climate) \\
\hline Kwon et al. & Ecol. Inform. & 2015 & 22 & 960 & Nation-wide & South Korea & PA & Climate, topography, hydrology \\
\hline Huang \& Frimpong & PLOS One & 2015 & 76 & 1933 & Four US basins & USA & PA & GIS (Geo, land use, climate) \\
\hline Labay et al. & Environ Manag. & 2015 & 100 & 269 & Texas & USA & PA & GIS (climate, geology, topography) \\
\hline Marie et al. & Aquatic Conserv. & 2015 & 35 & 139 & North France & France & PA & Local and GIS \\
\hline Harig \& Fausch & Ecol. Appl. & 2002 & 1 & 27 & 2 streams in Colorado R. Basin & USA & DC & habitats \& watershed \\
\hline Bouchard \& Boisclair & Can. J. Fish. Aquat. Sci. & 2008 & 1 & 32 & Saite-Marguerite R. (QC) & Canada & Den & local \& longitudinal \\
\hline \multirow[t]{2}{*}{ Steen et al. } & T. Am. Fish. Soc. & 2008 & 93 & $66-1242 *$ & State-wide (MI) & USA & PA & watershed (reach)_GIS \\
\hline & & & 46 & subset & State-wide (MI) & USA & $\mathrm{DC}$ & watershed (reach)_GIS \\
\hline Wenger \& Freeman & Ecology & 2008 & 1 & 215 & Etowah (GA) & USA & $\begin{array}{r}\text { PA \& } \\
\text { Den }\end{array}$ & local habitat \\
\hline McKenna \& Johnson & N. Am. J. Fish. Manage & 2011 & 1 & 7800 & State-wide (NY) & USA & Den & Watershed \\
\hline Boone et al. & Environmetrics & 2012 & 1 & 28 & Albert \& Mary R. Basins (QLD) & Australia & Den & local and watershed \\
\hline Maloney et al. & Env. Model Assess. & 2012 & 30 & 1640 & State-wide (MD) & USA & $\begin{array}{r}\text { PA \& } \\
\text { Den }\end{array}$ & watershed (GIS) \\
\hline McMillan et al. & T. Am. Fish. Soc. & 2013 & 1 & 7 & Calawah R. Basin (WA) & USA & Den & local habitats \\
\hline Stewart-Koster et al. & Ecography & 2013 & 1 & 28 & Albert \& Mary R. Basins (QLD) & Australia & $\begin{array}{r}\text { PA \& } \\
\text { Den }\end{array}$ & local and watershed \\
\hline Anlauf-Dunn et al & Can. J. Fish. Aquat. Sci. & 2014 & 1 & 651 & Coastal watersheds (OR) & USA & PA \&Den & habitats \\
\hline Troia \& Gido & Ecosphere & 2014 & 6 & 221 & Big Blue R. Basin (KS) & USA & Den & habitat \& watershed \\
\hline Cianfrani et al. & Ecol. Model. & 2015 & 1 & 21 & One catchment in Switzerland & Switzerland & Den & Climate, land-cover \\
\hline Lamouroux \& Olivier & Freshwat. Biol & 2015 & 14 & 9 & A catchment & Germany & Den & Hydraulic condition \\
\hline Walsworth \& Budy & TAFS & 2015 & 3 & 22 & A catchment (UT) & US & Den & Habitats, invasive species \\
\hline
\end{tabular}

* varying with species

${ }^{\wedge}$ Number of records 
Appendix 2. Description of 65 variables used for random-forests regression (WT = total watershed, $\mathrm{W}=$ local watershed, $\mathrm{R}=$ riparian zone in a local watershed, $\mathrm{RT}=$ riparian zone in the total watershed).

\begin{tabular}{|c|c|c|c|}
\hline Variables & Description & Variables & Description \\
\hline Stream Size (5) & & Landuse (12) (2002) & \\
\hline Link & number of upstream $1^{\text {st }}$-order streams & R_Water & $\%$ water in riparian zone $(\mathrm{W})$ \\
\hline Dlink & link of downstream reach & RT_Grass & $\%$ grassland in riparian zone $(\mathrm{WT})$ \\
\hline Order & stream Order (Shreve) & W_Forest & $\%$ forest $(\mathrm{W})$ \\
\hline Downorder & order of downstream reach & W_Agril & $\%$ agricultural land $(\mathrm{W})$ \\
\hline \multirow[t]{2}{*}{ WT_Area $\left(\mathrm{km}^{2}\right)$} & size of the total watershed & W_Grass & $\%$ Grass land $(\mathrm{W})$ \\
\hline & & W_Urban & $\%$ urban land $(\mathrm{W})$ \\
\hline Climate (3) (1961-1990) & & W_Water & $\%$ water $(\mathrm{W})$ \\
\hline WT_GDD & Growing-degree-days (WT) & W_Wet & $\%$ wetland $(\mathrm{W})$ \\
\hline WT_JMin $\left(\mathrm{C}^{\circ}\right)$ & July-minimum Temp (WT) & WT_Forest & $\%$ forest $(\mathrm{WT})$ \\
\hline \multirow[t]{2}{*}{ WT_Precip (mm) } & Annual precipitation (WT) & WT_Urban & $\%$ urban land (WT) \\
\hline & & WT_Grass & $\%$ grass land (WT) \\
\hline Geology (22) & & WT_Agril & $\%$ agricultural land (WT) \\
\hline Chan_BR50 & channel bedrock depth $<15 \mathrm{~m}$ & & \\
\hline Chan_BR100 & $15 \mathrm{~m} \leq$ channel bedrock depth $<30 \mathrm{~m}$ & Connections (15) & \\
\hline Chan_BRG100 & channel bedrock depth $\geq 30 \mathrm{~m}$ & \multirow{2}{*}{ Bigriver } & \multirow{2}{*}{$\begin{array}{r}0=\text { no direct connection to a river with the } \\
\text { total watershed }>1000 \mathrm{~km}^{2} ; 1=\text { yes }\end{array}$} \\
\hline WT_BR50 & $\%$ of WT with bedrock depth $<15 \mathrm{~m}$ & & \\
\hline WT_BR100 & $\%$ of WT with $15 \mathrm{~m} \leq$ bedrock depth $\leq 30 \mathrm{~m}$ & Damdn_L (m) & distance to the closest downstream dam \\
\hline WT_BRG100 & $\%$ of WT with bedrock depth $\geq 30 \mathrm{~m}$ & Damdnst & $1=$ downstream dam; $0=$ not \\
\hline WT_Carb & $\%$ of WT with carbonate (bedrock) & Damup_L (m) & distance to the closest upstream dam \\
\hline WT_Sand & $\%$ WT for sand (bedrock) & Damupst & $1=$ upstream dam, $0=$ not \\
\hline WT_Shale & $\%$ WT for shale (bedrock) & \multirow{2}{*}{ Missi } & $0=$ dam $/$ waterfall between target reach and \\
\hline WT_Rocky & $\%$ WT for bedrock-colluvium (deposit) & & Mississippi River; $1=$ no \\
\hline WT_Alluv & $\%$ of WT for alluvium (deposit) & \multirow{2}{*}{ Pond } & \multirow[t]{2}{*}{$1=$ a pond within the reach; $0=$ no } \\
\hline WT_CMorai & $\%$ of WT for coarse moraine (deposit) & & \\
\hline WT_Coars & $\%$ of WT for coarse (deposit) & Pondarea $\left(\mathrm{km}^{2}\right)$ & size of within-reach pond \\
\hline WT_Collu & $\%$ of WT for colluviums (deposit) & \multirow[t]{2}{*}{ Ponddn_L (m) } & distance to the nearest downstream pond of $\geq$ \\
\hline WT_Dune & $\%$ of WT for dune (deposit) & & $0.04 \mathrm{~km}^{2}$ \\
\hline WT_Fine & $\%$ of WT for all-form-fine (deposit) & Ponddn_S $\left(\mathrm{km}^{2}\right)$ & size of downstream pond $\geq 0.04 \mathrm{~km}^{2}$ \\
\hline WT_Lacus & $\%$ of WT for lacustrine (deposit) & Ponddn_S $\left(\mathrm{km}^{2}\right)$ & size of downstream pond $\geq 0.04 \mathrm{~km}^{2}$ \\
\hline WT_Loess & $\%$ of WT for loess (deposit) & Ponddnst & $\begin{array}{l}1=\text { downstream pond } \geq 0.04,0=\text { no } \\
\text { distance to the nearest unstream } \text { nond of }>\end{array}$ \\
\hline WT_MMora & $\%$ of WT for medium moraine (deposit) & Pondup_L (m) & $0.02 \mathrm{~km}^{2}$ \\
\hline WT_OWash & $\%$ of WT for outwash (deposit) & Pondup_S (acre) & size of nearest downstream pond $\geq 0.04 \mathrm{~km}^{2}$ \\
\hline WT_PMuck & $\%$ of WT for peat-muck (deposit) & Pondup_S (acre) & size of nearest downstream pond $\geq 0.04 \mathrm{~km}^{2}$ \\
\hline \multirow[t]{2}{*}{ WT_ICont } & $\%$ of WT for ice contact (deposit) & Pondupst & $1=$ upstream pond $\geq 0.02 \mathrm{~km}^{2}, 0=$ no \\
\hline & \multicolumn{3}{|c|}{ Topography (5) } \\
\hline Soil (4) & & Sinuosity & (Channel length)/(downstream distance) \\
\hline W_Darcy & Average Darcy Number & W_Area $\left(\mathrm{km}^{2}\right)$ & Size of the local watershed \\
\hline WT_Darcy & Average Darcy Index & & ArcInfo SLOPE command: \\
\hline W_Perm & Average Soil permeability (W) & W_Slope $(\%)$ & arctangent(rise $/$ run $) \times 57.296^{\mathrm{c}}$ \\
\hline \multirow[t]{2}{*}{ WT_Perm } & Average Soil Permeability (WT) & WT_Slope (\%) & $\begin{array}{r}\text { ArcInfo SLOPE command: } \\
\text { arctangent(rise/run) } \times 57.296^{\circ}\end{array}$ \\
\hline & & Chan-Grad (m) & Elevation change $(\mathrm{m}) /$ channel length $(\mathrm{m})$ \\
\hline
\end{tabular}


Appendix 3. Number of species that showed different types of directional responses to 38 environmental variables ranked as the top 10 predictors at least by one species in IL wadeable streams (see Appendix 2 for variable descriptions).

\begin{tabular}{|c|c|c|c|c|c|}
\hline Major Categories & Variables & Positive & Negative & multimodal & Total \\
\hline \multirow[t]{3}{*}{ Climate } & WT_GDD & 12 & 26 & 11 & 49 \\
\hline & $\mathrm{WT}^{-} \mathrm{Jmin}$ & 16 & 23 & 8 & 47 \\
\hline & WT_Precip & 19 & 23 & 4 & 46 \\
\hline \multirow[t]{2}{*}{ Stream size } & Link & 11 & 5 & & 16 \\
\hline & WT_Area & 7 & 7 & & 14 \\
\hline \multirow[t]{4}{*}{ Soil } & WT_Perm & 20 & 8 & 8 & 36 \\
\hline & W-Perm & 11 & 8 & 6 & 25 \\
\hline & WT_Darcy & 1 & 1 & & 2 \\
\hline & W_Darcy & 1 & & & 1 \\
\hline \multirow[t]{3}{*}{ Topography } & WT_Slope & 13 & 12 & 7 & 32 \\
\hline & W_Slope & 10 & 5 & 3 & 18 \\
\hline & CH_Grad & 4 & 2 & & 6 \\
\hline \multirow[t]{7}{*}{ Landuse } & WT_Forest & 11 & 15 & 9 & 35 \\
\hline & WT_Agri & 25 & 5 & 3 & 33 \\
\hline & RT_Grass & 3 & 2 & & 5 \\
\hline & WT_Grass & 3 & 2 & & 5 \\
\hline & R_Water & 1 & 3 & & 4 \\
\hline & W_Forest & 2 & 1 & & 3 \\
\hline & W_Wet & & 2 & & 2 \\
\hline \multirow[t]{11}{*}{ Geology } & WT_BR50 & 8 & 16 & 5 & 29 \\
\hline & WT_BG100 & 11 & 4 & & 15 \\
\hline & WT_Alluv & 4 & 1 & 1 & 6 \\
\hline & WT_Mmora & 5 & & & 5 \\
\hline & WT_Rocky & 4 & & & 4 \\
\hline & WT_Collu & 3 & & & 3 \\
\hline & WT_Fine & 1 & 1 & 1 & 3 \\
\hline & WT_Shale & 2 & 1 & & 3 \\
\hline & WT_Carbon & 1 & 1 & & 2 \\
\hline & WT_Lacus & 1 & & & 1 \\
\hline & WT_Owash & & & 1 & 1 \\
\hline \multirow[t]{6}{*}{ Connection } & Damdn_L & 13 & 2 & 2 & 17 \\
\hline & Ponddn_L & 9 & 1 & & 10 \\
\hline & Ponddn_S & 9 & & 1 & 10 \\
\hline & Dlink & 2 & 2 & & 4 \\
\hline & BigRiver & 1 & & & 1 \\
\hline & Downorder & 1 & & & 1 \\
\hline
\end{tabular}

